\title{
Article \\ GHGs Emission from the Agricultural Sector within EU-28: A Multivariate Analysis Approach
}

\author{
Endre Harsányi ${ }^{1}$, Bashar Bashir $\left.{ }^{2}{ }^{(}\right)$, Gafar Almhamad ${ }^{3}{ }^{\circ}$, Omar Hijazi $^{4}$, Mona Maze ${ }^{5}$, Ahmed Elbeltagi ${ }^{6}{ }^{(D}$,

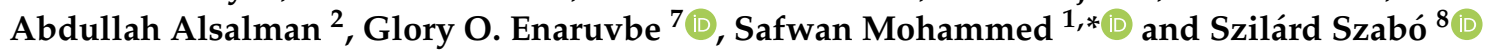 \\ 1 Faculty of Agricultural and Food Sciences and Environmental Management, Institute of Land Utilization, \\ Technology and Regional Development, University of Debrecen, Böszörményi Str. 138, \\ 4032 Debrecen, Hungary; harsanyie@agr.unideb.hu \\ 2 Department of Civil Engineering, College of Engineering, King Saud University, P.O. Box 800, \\ Riyadh 11421, Saudi Arabia; bbashir@ksu.edu.sa (B.B.); asalman@ksu.edu.sa (A.A.) \\ 3 Institute of Management and Organization Sciences, Debrecen University, 4032 Debrecen, Hungary; \\ Almhamad.gafar@econ.unideb.hu \\ 4 Chair of Wood Science, Technical University of Munich, 85354 Freising, Germany; hijazi@hfm.tum.de \\ 5 Central Laboratory for Agricultural Climate (CLAC), Agricultural Research Center, Giza 12613, Egypt; \\ mona_maze@yahoo.de \\ 6 Agricultural Engineering Department, Faculty of Agriculture, Mansoura University, Mansoura 35516, Egypt; \\ ahmedelbeltagy81@mans.edu.eg \\ 7 African Regional Institute for Geospatial Information Science and Technology, Obafemi Awolowo University, \\ Ile-Ife 220282, Nigeria; enaruvbe@gmail.com \\ 8 Department of Physical Geography and Geoinformatics, University of Debrecen, Egyetem tér 1, \\ 4032 Debrecen, Hungary; szabo.szilard@science.unideb.hu \\ check for \\ updates \\ * Correspondence: safwan@agr.unideb.hu
}

Citation: Harsányi, E.; Bashir, B.; Almhamad, G.; Hijazi, O.; Maze, M.; Elbeltagi, A.; Alsalman, A.;

Enaruvbe, G.O.; Mohammed, S.; Szabó, S. GHGs Emission from the Agricultural Sector within EU-28: A Multivariate Analysis Approach. Energies 2021, 14, 6495. https:// doi.org/10.3390/en14206495

Academic Editor: Piotr Gradziuk

Received: 7 September 2021

Accepted: 6 October 2021

Published: 11 October 2021

Publisher's Note: MDPI stays neutral with regard to jurisdictional claims in published maps and institutional affiliations.

Copyright: (c) 2021 by the authors. Licensee MDPI, Basel, Switzerland. This article is an open access article distributed under the terms and conditions of the Creative Commons Attribution (CC BY) license (https:/ / creativecommons.org/licenses/by/ $4.0 /)$.
Abstract: Climate mitigation and adaptation planning (CMAP) has recently been implemented across the EU-28 to reduce GHG emissions $\left(\mathrm{CO}_{2}, \mathrm{CH}_{4}, \mathrm{~N}_{2} \mathrm{O}\right)$. Thus, the aim of this study was to provide an overview of GHG emissions from the agricultural sector in the EU-28 from 1990 to 2019, and cluster the EU-28 countries regarding their total GHG emissions. The results emphasize the positive impact of CMAP through a negative trend of the total GHG emissions ( -2653.01 thousand tons/year, $p<0.05)$. Despite the positive and not significant trend of the total $\mathrm{CO}_{2}$ emissions, both $\mathrm{CH}_{4}$ and $\mathrm{N}_{2} \mathrm{O}$ exhibited a negative and significant trend. At the country scale, Italy, the United Kingdom, and the Netherlands showed the highest reduction in total GHG emissions, by -282.61thousand tons/year $(p<0.05),-266.40$ thousand tons/year $(p<0.05)$, and -262.91 thousand tons/year $(p<0.05)$, respectively. The output of the multivariate analysis approach indicates changes in the pattern of GHG emissions between 1990 and 2019, where $\mathrm{CO}_{2}$ emissions decreased in the case of Poland and Czechia. The output of this study highlights the positive impact of CMAP, adopted by EU countries, in minimizing GHG emissions. Despite some fluctuations in $\mathrm{CO}_{2}$ emissions, strategies for attaining carbon neutrality in the agricultural sector, across the European Union, should be pursued.

Keywords: climate policy; GHGs emissions; PCA; IPCC; CSA

\section{Introduction}

Rapid population growth and the concomitant increase in anthropogenic activities have resulted in climate change-induced challenges, and pose major threats to the sustainability of natural resources and the stability of the Earth's biosphere, especially in the recent past [1]. These challenges are leading to uncontrolled accumulation of greenhouses gases in the Earth's atmosphere [2]. The global concentration of greenhouse gas emissions (GHGs) has been accelerating particularly rapidly since the beginning of the industrial era because of various anthropogenic activities [3]; for instance, although the concentration of $\mathrm{CO}_{2}$ in the $1760 \mathrm{~s}$ was $280 \mathrm{ppm}$, the current estimate is $410 \mathrm{ppm}$, and is expected to reach 
$590 \mathrm{ppm}$ by the end of 2100 [2]. The global tracking of greenhouse gas emissions provides a framework for assessing the contribution of individual countries to the climate change challenge. Climate change indicators define the emissions of the most significant GHGs from human activity, atmospheric concentrations, and how emissions and concentrations have evolved over time $[4,5]$. These indicators employ the concept of "global warming potential" for comparing the emissions of gases, in order to convert the quantities of other gases into $\mathrm{CO}_{2}$ equivalents. The emissions of GHGs from human activities are rising and exacerbating climate change. This increasing level of GHGs is resulting in many more climate-related changes at the local to global scale [6].

Since the beginning of the industrial age, $\mathrm{CO}_{2}$ and other GHGs in the atmosphere have been on the rise, primarily because of human activity. The net emissions of greenhouse gasses from human activities worldwide increased to 43\% between 1990 and 2015. During this period, carbon dioxide emissions, representing approximately $35 \%$ of the total emissions, have grown by $51 \%$ [7]. The industrial and agricultural sectors accounted for $31.6 \%$ and $13.8 \%$, respectively, and were considered to be major sources of GHG emissions, while $12.2 \%$ of the emissions came from land use changes [8]. Unpredictably, GHG emissions from the agricultural sector increased by 1.1\% between 2000 and 2010 [9]. Many factors, such as agricultural expansion and/or intensification, deforestation, land clearing, fertilization, livestock production, and traditional soil management and cultivation, alter the global geochemical cycle and enhance GHG emissions from the agricultural sector, especially in developing countries [10]. Interestingly, Tian et al. [11] reported that $87 \%$ of the total $\mathrm{N}_{2} \mathrm{O}$ emissions originated from the agricultural sector ( $71 \%$ agricultural $+16 \% \mathrm{~N}$-fertilization), with cropland farming accounting for roughly $5 \%$ of all anthropogenic GHG emissions [12]. Therefore, many databases and analyses were developed to address the current and future contribution of the agricultural sector to climate change, and formulate adaptation and mitigation strategies. Politically, the assessment of GHG emissions from the agricultural sector, along with related sectors, such as forestry and other land use (i.e., AFOLU), will support the discussion about the role of agriculture in climate mitigation within the United Nations Climate Change Conference (COP26).

Recently, the GHG emissions from the European Union's agricultural sector were estimated to be $10 \%$ of the total GHG emissions [13]. Although the total amount of EU-27 GHG emissions in 2019 was $4.065 \mathrm{MtCO}_{2 \mathrm{e}}$ [14], the annual estimate of GHG emissions by agriculture was 436 million tons [15]. This suggests that energy is one of the main inputs in the agricultural system [16], whereas the energy from creating fossil fuels is mainly utilized by agriculture and multiple other actions, including forestry, which form $2.78 \%$ of the European Union correlated activities [17]. The Netherlands has the highest share of agricultural energy usage, with 8.1 percent, followed by Poland, which has 5.6 percent. In contrast, Romania accounts for the lowest percentage overall [18]. The growing quantity of energy is due to the neoteric agricultural activities, which are partly responsible for the persistent increase in GHG emissions [19]. About half of the energy used in the agricultural sector is derived from diesel and gas oil, which make up the highest share of energy utilized in the agricultural sector in the EU [15]. Regardless of the size and variation in the contribution of the agricultural sector in the national GDP in each member country of the $\mathrm{EU}$, the EU has achieved a 23\% reduction in GHG emissions in the last two decades [13].

Since its foundation, the EU has adopted many strategies, plans, and programs for environmental sustainability, with emphasis on energy management and the reduction in GHG emissions $[20,21]$. The common agricultural policy (CAP) is a policy created by the European Union, with the aim of implementing activities to integrate climate change reduction procedures into its policies [22]. During 2014-2020, over one hundred billion Euros, accounting for about $25 \%$ of the CAP budget, was the contribution of the commission to reduce, alleviate, and adjust to climate change. The European Green Deal strategy has recently been adopted, which is designed to promote climate neutral actions and resource-efficient consumption [20,23]. Many studies were carried out to assess lowcarbon economy (LCE) within the agricultural sector. In view of this, Piwowar et al. [24] 
stress the importance of raising the awareness of farmers about LCE practice in rural areas of Poland. In Spain, Baccour et al. [25] suggested that a combination of measures could help reduce GHG emissions from the agricultural sector by $75 \%$. Interestingly, Bajan et al. [20] proved that the usage of renewable energy in food production is approaching the expected strategic goals within V4 countries (Czechia, Slovakia, Hungary, Poland), resulting in some of the successes recorded in the reduction in GHG emissions from the agricultural sector in some EU countries (1990-2018). However, EU polices in agricultural sector led to a reduction of GHG emissions [26].

Promoting efforts towards minimizing GHG emissions at the field scale are required to attain the aspiration of GHG reduction in Europe by 2050 [27]. In addition to an efficient energy toolkit, water and carbon footprints for agriculture output are being established by the European Union. This is aimed at reducing water shortage, enhancing energy efficiency, and excluding gas emissions by 2050 [28]. The objectives laid out under the EU effort sharing law may vary slightly among member states, and there are exceptions, even though most EU member states do not have agricultural targets. The Netherlands, for instance, has established an emission reduction target of $3.5 \mathrm{MtCO}_{2} \mathrm{eq} \mathrm{yr}^{-1}$ by 2030, which should be reached by the co-funding of mitigation measures, and governmental and business cooperation in their National Agreement on Climate Change (NACC) [29]. Other member states have set carbon budgets in their national low-carbon strategy. France, for example, projected a cut in GHG emissions of $8 \%$ by $2023,13 \%$ by 2028 , and $20 \%$ by 2033 , based on a benchmark of the 2015 levels [30]. The UK has also created carbon budgets that have strategic sector objectives, including a $20 \%$ reduction in agriculture, forestry, and other land use emissions from 2016 to 2030 [31]. In its 2050 climate action plan, Germany has more aggressive targets of reducing agriculture emissions by 31-34\% in 2030, using a 1990 benchmark [32]. The climate action plan of Ireland provides a de-carbonization route to 2030, consistent with the adoption, by 2050, of net zero emission objectives [33]. There are some measures for reducing GHGs from the agricultural sector, such as cost-effectiveness analysis [34], reducing water consumption in different agricultural systems [35], no or reduced tillage (NT/RT) combined with crop rotations (i.e., legumes and cover crops) [36], and others $[37,38]$. On this basis, the objective of this study was to (1) evaluate the changes in GHG emissions from the agricultural sector of the EU-28 from 1990 to 2019, and (2) cluster the EU-28 countries regarding their total GHG emissions.

\section{Materials and Methods}

\subsection{Data Collection}

Data for the EU-28 countries between 1990 and 2019 were collected from the European Environment Agency (EEA) [39] (Table 1). These data were checked and updated in June 2021. All countries and their abbreviations are listed in Table 2.

Table 1. Type of collected data.

\begin{tabular}{ccc}
\hline Data Type & Unit & Time Frequency \\
\hline Total GHGs emission from agricultural sector * & Thousand tons & Annual \\
$\mathrm{CO}_{2}$ & Thousand tons & Annual \\
$\mathrm{CH}_{4}\left(\mathrm{CO}_{2}\right.$ equivalent $)$ & Thousand tons & Annual \\
$\mathrm{N}_{2} \mathrm{O}\left(\mathrm{CO}_{2}\right.$ equivalent $)$ & Thousand tons & Annual \\
\hline
\end{tabular}

* Greenhouse gases $\left(\mathrm{CO}_{2}, \mathrm{~N}_{2} \mathrm{O}\right.$ in $\mathrm{CO}_{2}$ equivalent, $\mathrm{CH}_{4}$ in $\mathrm{CO}_{2}$ equivalent, $\mathrm{HFC}$ in $\mathrm{CO}_{2}$ equivalent, $\mathrm{PFC}$ in $\mathrm{CO}_{2}$ equivalent, $\mathrm{SF} 6$ in $\mathrm{CO}_{2}$ equivalent, $\mathrm{NF}_{3}$ in $\mathrm{CO}_{2}$ equivalent).

\subsection{Trend Analysis}

Trend analysis could be conducted using parametric and non-parametric methods. Despite the effectiveness of parametric methods, they require independent and normally distributed data. In contrast, non-parametric methods simply require independent data [40]. In this research, the Mann-Kendall (MK) test [41,42] was used for detecting trend of GHGs across EU-28 countries. The MK is a well-known rank-based non-parametric test used to 
detect decrease $(-)$ or increase $(+)$ for studied variables through time. The advantage of using the MK test is that data do not have to be normally distributed, and they are not affected by outliers. The null hypothesis $\left(H_{0}\right)$ in MK test states that there is no trend over time. For time series $X=\left(X_{1}, X_{2}, \ldots X_{n}\right)$, the static test of MK (S) could be interoperated as shown in Equations (1) and (2) as follow [41,42]:

$$
\begin{gathered}
S=\sum_{i=1}^{N-1} \sum_{j=i+1}^{N} \nabla_{i j} \\
\nabla_{i j}=\operatorname{sign}\left(x_{j}-x_{i}\right)= \begin{cases}1 & x_{j}>x_{i} \\
0 & x_{j}=x_{i} \\
-1 & x_{j}<x_{i}\end{cases}
\end{gathered}
$$

where $\mathrm{N}$ : length of the data, $\mathrm{x}_{\mathrm{i}}$ and $\mathrm{x}_{\mathrm{j}}$ : observations.

The variance in $S$ is denoted as shown in Equation (3), as follows:

$$
\operatorname{Var}(S)=\frac{n(n-1)(2 n+5)-\sum_{i=1}^{P} t_{i}\left(t_{i}-1\right)\left(2 t_{i}+5\right)}{18}
$$

where P: tied group, $\mathrm{t}_{\mathrm{i}}$ : number of data. Then $\mathrm{Z}$ standard can be calculated. More details about MK calculations could be found in [40].

In this study the $\mathrm{M}_{\mathrm{k}}$ was adopted for detecting the trend of GHG emissions to overcome the presence of outliers and skewed data [43]. Also, the Sen slope $(\rho)$ [44] was used to determine the amount of GHG changes per time. The $\rho$ is a non-parametric method that captures the slope of the trend in a dataset ( $\mathrm{N}$ pairs) as depicted in Equations (4) and (5), as follows:

$$
\rho=\frac{x_{j}-x_{i}}{j-k}(j>k)
$$

where $x_{j}, x_{i}$ are values of the data. Then the median of $\rho$ is computed as follows:

$$
\rho_{\text {median }}= \begin{cases}\frac{\rho_{(\mathrm{N}+1)}}{2} & \text { if } \mathrm{N} \text { is odd } \\ \frac{\rho_{\left(\frac{\mathrm{N}}{2}\right)}+\rho_{\frac{(\mathrm{N}+2)}{2}}}{2} & \text { if } \mathrm{N} \text { is even }\end{cases}
$$

\subsection{Multivariate Analysis}

Principal component analysis (PCA) is a multivariate method for reducing a large number of inter-correlated quantitative data (dependent variables) to a smaller number of representative variables, known as principal components (PCs), by employing complex underlying mathematical functions $[45,46]$. In this study, the similarities and differences in GHG emissions $\left(\mathrm{CO}_{2}, \mathrm{CH}_{4}\right.$ and $\left.\mathrm{NO}_{2}\right)$ across EU-28 were determined using principal component analysis (PCA). The PCA was performed with the standardized approach using the correlation matrix to reveal the pattern of GHG emissions $\left(\mathrm{CO}_{2}, \mathrm{CH}_{4}\right.$ and $\left.\mathrm{NO}_{2}\right)$ in the ordination space defined by the principal components (PCs).

To show the differences between GHG emissions in 1990 and 2019, we conducted two PCAs by using biplots. Biplots can depict the cases considering the three dimensions with the correlations. We tested the model fit with the root mean square residual (RMSR), where values $<0.1$ are considered good and $<0.05$ indicated very good [47].

The EU-28 countries were divided into the following 6 groups: western (w) (Belgium, France, Luxemburg, the Netherlands, Ireland, the United Kingdom); northern (n) (Denmark, Finland, Sweden, Iceland); middle (m) (Austria, Germany); southern (s) (Greece, Spain, Italy, Cyprus, Portugal); post-socialist (Bulgaria, Estonia, Croatia, Latvia, Lithuania, Romania, Slovenia); and Visegrad 4s (v4) (Czechia, Slovakia, Hungary, Poland) based on their location and historical basis (having the heritage of communism on the economy). Using these groups, we tested the following hypothesis: $\mathrm{H}_{0}$ that each group 
was from the same statistical population with the same medians using Kruskal-Wallis test. We performed the test with PCs of the PCA for the dataset of 1990 and 2019.

We also conducted a cluster analysis on the GHG emissions with the change, i.e., the ratio of 2019 and 1990 as percentages. We applied the Ward's method and the output was visualized with a hierarchical dendrogram and in boxplot diagram.

\section{Empirical Findings}

\subsection{Trend Analysis of GHGs Emissions between 1990 and 2019}

3.1.1. Total GHGs Emissions between 1990 and 2019

The result of the MK test indicated that there was a significant decline in GHG emissions from the agricultural sector in the majority of the EU-28 countries (Figure 1, Table 2). Table 2 shows that 20 European countries, Belgium (BE), Czechia (CZ), Denmark (DK), Germany (DE), Greece (EL), France (FR), Croatia (HR), Italy (IT), Latvia (LV), Malta (MT), the Netherlands (NL), Austria (AT), Poland (PL), Portugal (PT), Romania (RO), Slovenia (SI), Slovakia (SK), Finland (FI), Sweden (SE), and the United Kingdom (UK), had significant $(p<0.05)$ negative trends. The GHG emission trends were negative, but not significant, in Bulgaria (BG), Cyprus (CY), Lithuania (LT), Luxembourg (LU), and Iceland (IS). In contrast, positive, but not significant, trends were recorded in Estonia (EE), Ireland (IE), Spain (ES), and Hungary $(\mathrm{HU})$.
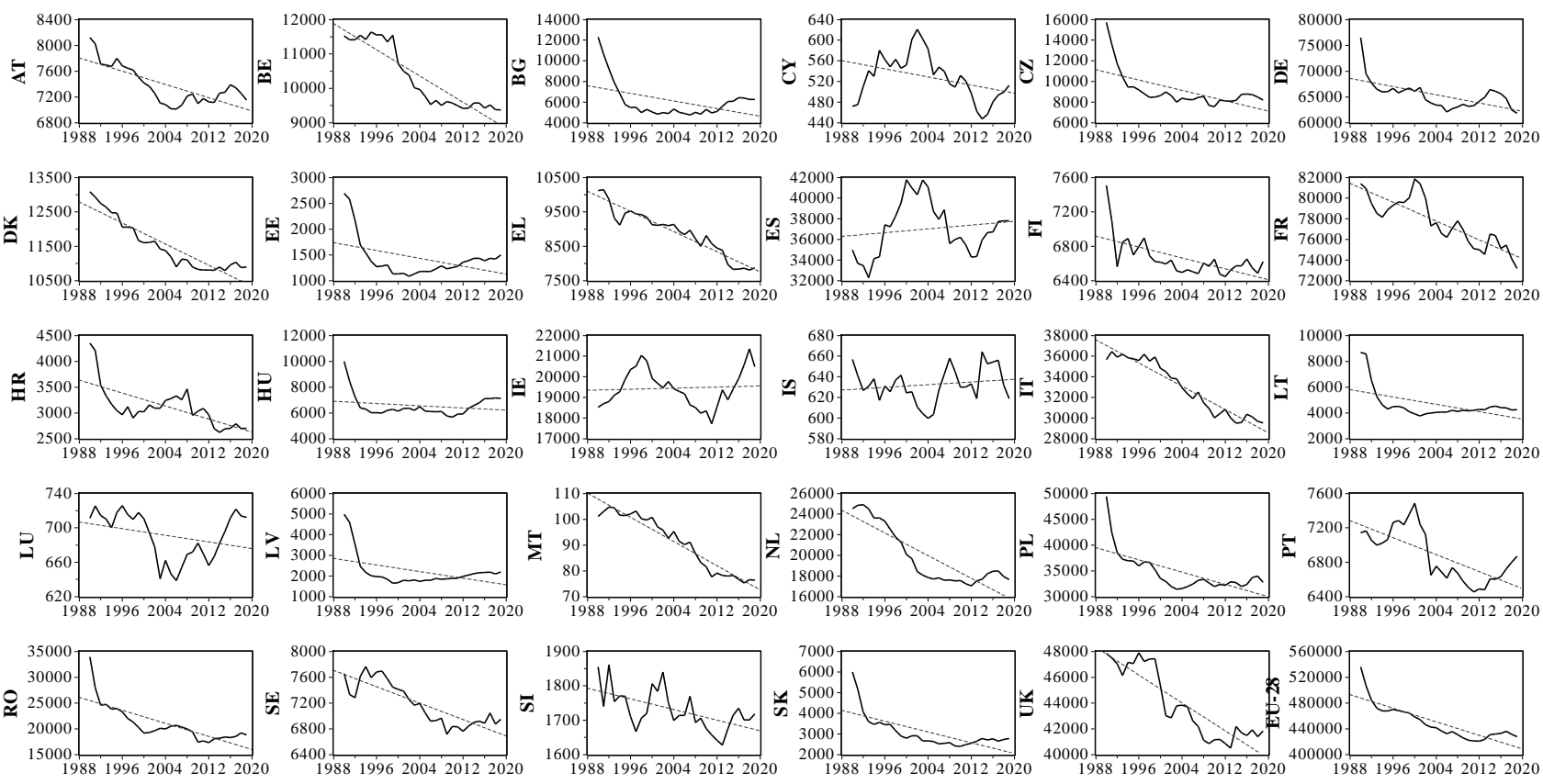

Figure 1. Time evolution of total GHG emissions between 1990 and 2019 from agricultural sector within EU-28.

The highest reduction in GHG emissions was recorded in IT $(-282.61$ thousand tons/year, $p<0.05)$, followed by the UK $(-266.40$ thousand tons/year, $p<0.05)$, and NL $(-262.91$ thousand tons/year, $p<0.05)$. The lowest reduction was recorded in MT $(-1.18$ thousand tons/year, $p<0.05)$, and SI $(-3.55$ thousand tons/year, $p<0.05)$. Nonetheless, the total emissions from the EU-28 depicted a significant reduction by -2653.01 thousand tons/year.

\subsection{2. $\mathrm{CO}_{2}$ Emissions between 1990 and 2019}

The majority of the EU-28 countries exhibited a positive $\mathrm{CO}_{2}$ emissions trend from the agricultural sector between 1990 and 2019 (Figure 2, Table 2). Only a few countries showed a negative significant trend, e.g., DK $(-8.98$ thousand tons/year, $p<0.05)$, EL $(-1.03$ thousand tons/year, $p<0.05)$, IT $(-5.26$ thousand tons/year, $p<0.05), \mathrm{CY}$ 
( -0.05 thousand tons/year, $p<0.05)$, NL ( -0.99 thousand tons/year, $p<0.05)$, PL $(-33.94$ thousand tons/year, $p<0.05)$, SI $(-0.81$ thousand tons/year, $p<0.05)$, FI $(-11.44$ thousand tons/year, $p<0.05)$, and SE $(-1.05$ thousand tons/year, $p<0.05)$. In contrast, some EU countries exapted a positive significant trend, such as BG ( +0.57 thousand tons/year, $p<0.05), \mathrm{CZ}(+5.41$ thousand tons/year, $p<0.05), \mathrm{DE}(+16.33$ thousand tons/year, $p<0.05)$, FR (+9.17 thousand tons/year, $p<0.05)$, HR ( +1.16 thousand tons/year, $p<0.05)$, LU $(+0.17$ thousand tons/year, $p<0.05)$, AT $(+2.7$ thousand tons/year, $p<0.05)$, and IS $(+0.13$ thousand tons/year, $p<0.05)$. Nonetheless, the rest of the EU countries showed positive, but not significant, trends (Table 2).

Table 2. Trend analysis of GHG emissions and its component across EU-28 countries between 1990 and 2019.

\begin{tabular}{|c|c|c|c|c|c|c|c|c|c|}
\hline \multicolumn{2}{|c|}{ EU-28 Countries } & \multicolumn{2}{|c|}{$\begin{array}{c}\text { Total GHGs } \\
\text { Emissions }\end{array}$} & \multicolumn{2}{|c|}{$\mathrm{CO}_{2}$} & \multicolumn{2}{|c|}{$\mathrm{CH}_{4}$} & \multicolumn{2}{|c|}{$\mathrm{N}_{2} \mathrm{O}$} \\
\hline & & $\rho$ & MK & $\rho$ & MK & $\rho$ & MK & $\rho$ & MK \\
\hline Total * & EU-28 & $<0.0001$ & -2653.01 & 0.42 & -9.61 & $<0.0001$ & -1675.72 & $<0.0001$ & -916.06 \\
\hline Belgium & $\mathrm{BE}$ & $<0.0001$ & -92.22 & 0.97 & 0.01 & $<0.0001$ & -31.48 & $<0.0001$ & -61.12 \\
\hline Bulgaria & BG & 0.38 & -22.62 & 0.00 & 0.57 & $<0.0001$ & -42.93 & 0.24 & 23.42 \\
\hline Czechia & $\mathrm{CZ}$ & $<0.0001$ & -65.77 & 0.00 & 5.41 & $<0.0001$ & -65.89 & 0.70 & -3.03 \\
\hline Denmark & DK & $<0.0001$ & -78.51 & $<0.0001$ & -8.98 & 0.00 & -7.76 & $<0.0001$ & -55.91 \\
\hline Germany & $\mathrm{DE}$ & 0.00 & -166.74 & 0.02 & 16.33 & $<0.0001$ & -177.53 & 0.83 & 5.06 \\
\hline Estonia & $\mathrm{EE}$ & 0.72 & 3.00 & 0.40 & 0.14 & 0.83 & -1.22 & 0.30 & 3.55 \\
\hline Ireland & IE & 0.86 & 3.90 & 0.94 & 0.15 & 0.06 & 27.96 & 0.02 & -22.92 \\
\hline Greece & EL & $<0.0001$ & -73.27 & $<0.0001$ & -1.03 & 0.09 & -6.02 & $<0.0001$ & -58.88 \\
\hline Spain & ES & 0.34 & 66.99 & 0.32 & 1.69 & 0.92 & 9.10 & 0.05 & 52.44 \\
\hline France & FR & $<0.0001$ & -227.20 & $<0.0001$ & 9.17 & $<0.0001$ & -122.76 & $<0.0001$ & -109.34 \\
\hline Croatia & HR & 0.00 & -24.17 & 0.00 & 1.16 & $<0.0001$ & -16.16 & 0.00 & -11.35 \\
\hline Italy & IT & $<0.0001$ & -282.61 & 0.00 & -5.26 & $<0.0001$ & -136.56 & $<0.0001$ & -143.50 \\
\hline Cyprus & $\mathrm{CY}$ & 0.02 & -2.37 & $<0.0001$ & -0.05 & 0.75 & -0.11 & 0.00 & -2.16 \\
\hline Latvia & $\mathrm{LV}$ & 0.57 & 5.62 & 0.01 & 0.74 & 0.36 & -4.73 & 0.04 & 7.97 \\
\hline Lithuania & $\mathrm{LT}$ & 0.34 & -7.94 & 0.34 & 0.19 & $<0.0001$ & -34.91 & 0.00 & 24.14 \\
\hline Luxembourg & LU & 0.17 & -0.91 & $<0.0001$ & 0.17 & 0.34 & 0.51 & $<0.0001$ & -1.61 \\
\hline Hungary & $\mathrm{HU}$ & 1.00 & 0.07 & 0.18 & 2.44 & $<0.0001$ & -33.08 & $<0.0001$ & 37.97 \\
\hline Malta & MT & $<0.0001$ & -1.18 & - & - & $<0.0001$ & -0.82 & $<0.0001$ & -0.37 \\
\hline Netherlands & NL & $<0.0001$ & -262.91 & 0.01 & -0.99 & 0.00 & -92.96 & $<0.0001$ & -173.15 \\
\hline Austria & $\mathrm{AT}$ & 0.00 & -27.57 & $<0.0001$ & 2.70 & $<0.0001$ & -21.41 & 0.00 & -7.01 \\
\hline Poland & PL & 0.00 & -216.02 & $<0.0001$ & -33.94 & $<0.0001$ & -137.11 & 0.03 & -36.94 \\
\hline Portugal & $\mathrm{PT}$ & 0.00 & -24.21 & 0.83 & 0.03 & 0.00 & -14.47 & 0.01 & -10.32 \\
\hline Romania & $\mathrm{RO}$ & $<0.0001$ & -257.30 & 0.13 & 0.77 & $<0.0001$ & -187.77 & 0.02 & -72.44 \\
\hline Slovenia & SI & 0.00 & -3.55 & $<0.0001$ & -0.81 & 0.18 & -1.04 & 0.00 & -1.56 \\
\hline Slovakia & SK & $<0.0001$ & -43.52 & 0.42 & 0.54 & $<0.0001$ & -40.52 & 0.48 & -3.10 \\
\hline Finland & FI & 0.00 & -11.64 & $<0.0001$ & -11.44 & 0.01 & -3.27 & 0.14 & 2.70 \\
\hline Sweden & SE & $<0.0001$ & -32.85 & 0.02 & -1.05 & $<0.0001$ & -18.21 & $<0.0001$ & -15.46 \\
\hline Iceland & IS & 0.46 & 0.27 & 0.00 & 0.13 & 0.13 & -0.45 & 0.02 & 0.49 \\
\hline $\begin{array}{l}\text { United } \\
\text { Kingdom }\end{array}$ & UK & $<0.0001$ & -266.40 & 0.17 & 8.47 & $<0.0001$ & -161.26 & $<0.0001$ & -115.55 \\
\hline
\end{tabular}

\subsection{3. $\mathrm{CH}_{4}$ Emissions between 1990 and 2019}

The total emissions of $\mathrm{CH}_{4}$ from the agricultural sector decreased significantly across the EU-28 (Table 2, Figure 3). The highest significant reduction was recorded in RO $(-187.77$ thousand tons/year, $p<0.05)$, DK $(-177.53$ thousand tons/year, $p<0.05)$, the UK $(-166$ thousand tons/year, $p<0.05)$, and PL $(-137.11$ thousand tons/year, $p<0.05)$. Despite the negative significant changes in $\mathrm{CH}_{4}$, some countries, e.g., $\mathrm{EE}, \mathrm{CY}, \mathrm{LV}, \mathrm{SI}$, and IS, exhibited a negative, but not significant, trend. Notably, apart from IE (+27.96 thousand tons/year, $p>0.05)$, ES (9.10 thousand tons/year, $p>0.05)$, and LU (0.51 thousand tons/year, most of the EU-28 countries witnessed a negative trend of $\mathrm{CH}_{4}$ emissions $(p>0.05)$ (Table 2, Figure 3). 

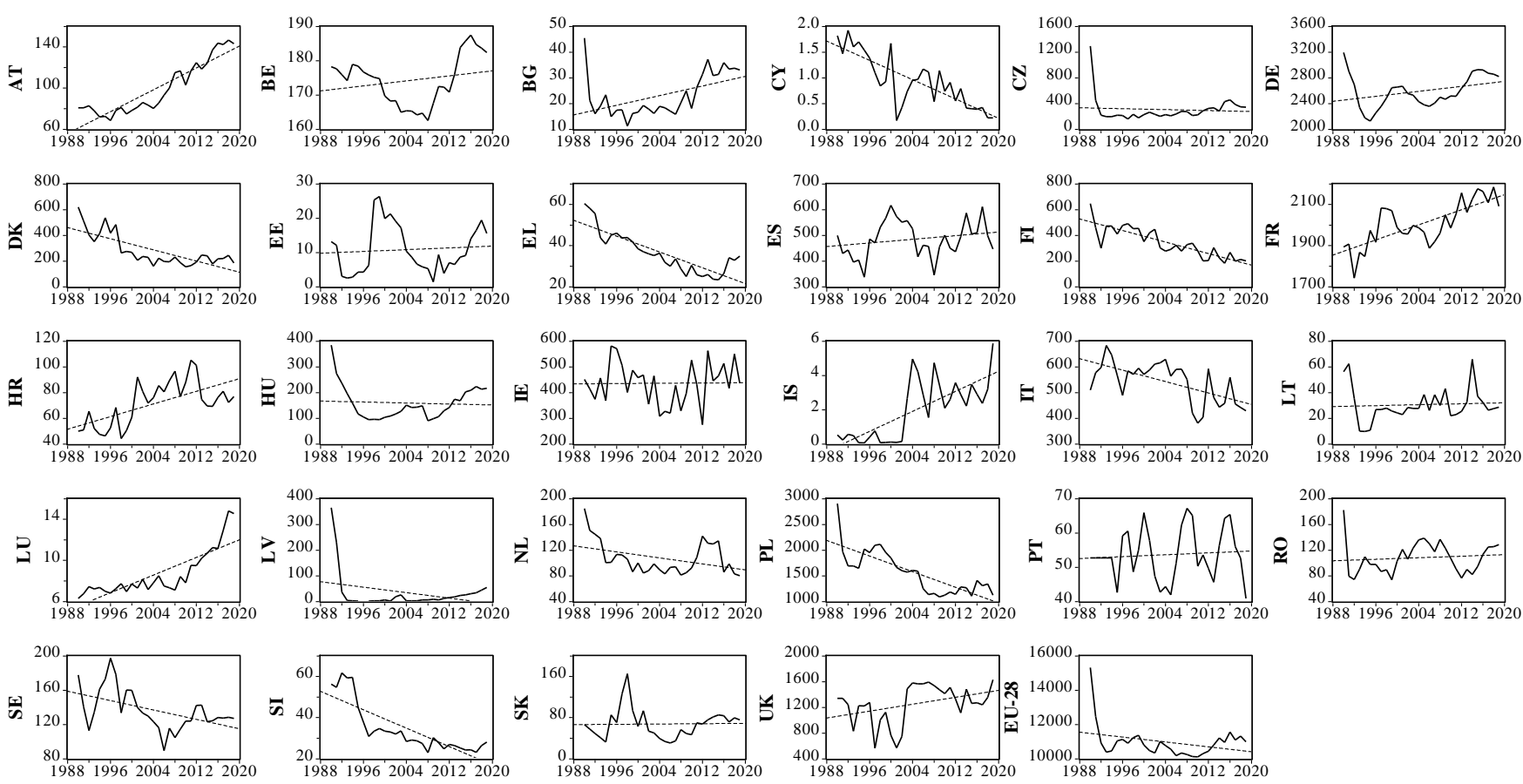

Figure 2. Time evolution of $\mathrm{CO}_{2}$ emissions between 1990 and 2019 within EU-28 (agricultural sector).
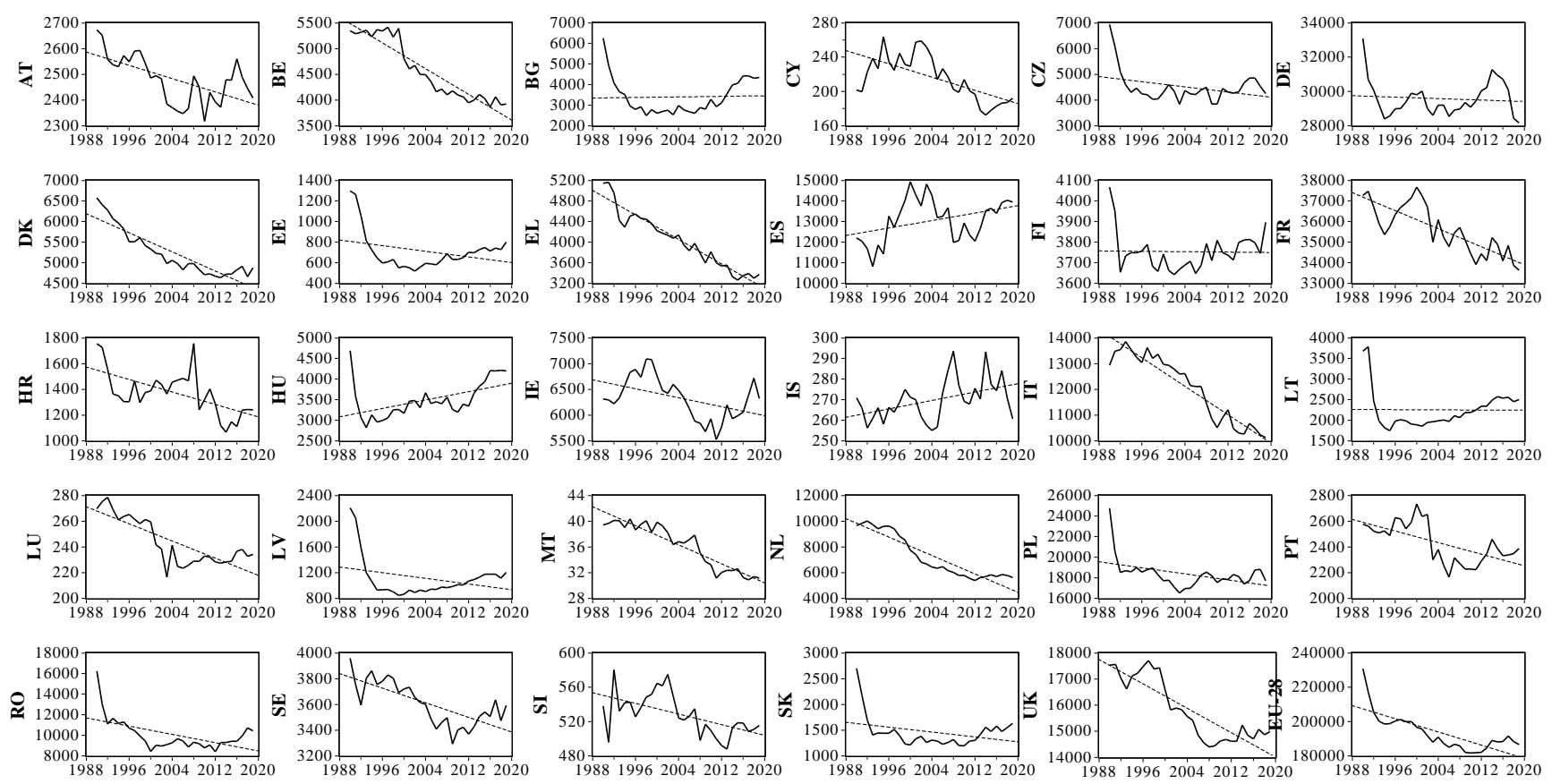

Figure 3. Time evolution of $\mathrm{CH}_{4}$ emissions between 1990 and 2019 within EU-28 (agricultural sector).

\subsection{4. $\mathrm{N}_{2} \mathrm{O}$ Emissions between $1990-2019$}

Similarly to $\mathrm{CH}_{4}$ emissions, $\mathrm{N}_{2} \mathrm{O}$ emissions exhibited a negative trend from most of the EU-28 countries (Table 2, Figure 4). The total reduction in $\mathrm{N}_{2} \mathrm{O}$ emissions from all the EU-28 countries was -916 thousand tons/year $(p<0.05)$ (Table 2). However, some countries showed a significant positive trend of $\mathrm{N}_{2} \mathrm{O}$ emissions; for instance, $\mathrm{LV}$ (+7.79 thousand tons/year, $p<0.05)$, LT $(+24.14$ thousand tons/year, $p<0.05)$, HU ( +37.97 thousand tons/year, $p<0.05)$, and IS (0.49 thousand tons/year, $p<0.05)$. On the other hand, some other countries, such as BG $(+23.42$ thousand tons/year, $p>0.05)$, 
$\mathrm{DE}(+5.06$ thousand tons/year, $p>0.05)$, EE (+3.5 thousand tons/year, $p>0.05)$, ES $(+52.44$ thousand tons/year, $p>0.05)$, and FI (2.7 thousand tons/year, $p>0.05)$, showed a positive, but not significant, trend in $\mathrm{N}_{2} \mathrm{O}$ emissions. Interestingly, the other EU countries showed a significant negative trend of $\mathrm{N}_{2} \mathrm{O}$ emissions, whereas the highest value of reduction was recorded in NL $(-143.5$ thousand tons/year, $p<0.05)$, followed by IT $(-143.5$ thousand tons/year, $p<0.05)$, then the UK $(-115.55$ thousand tons /year, $p<0.05)$.
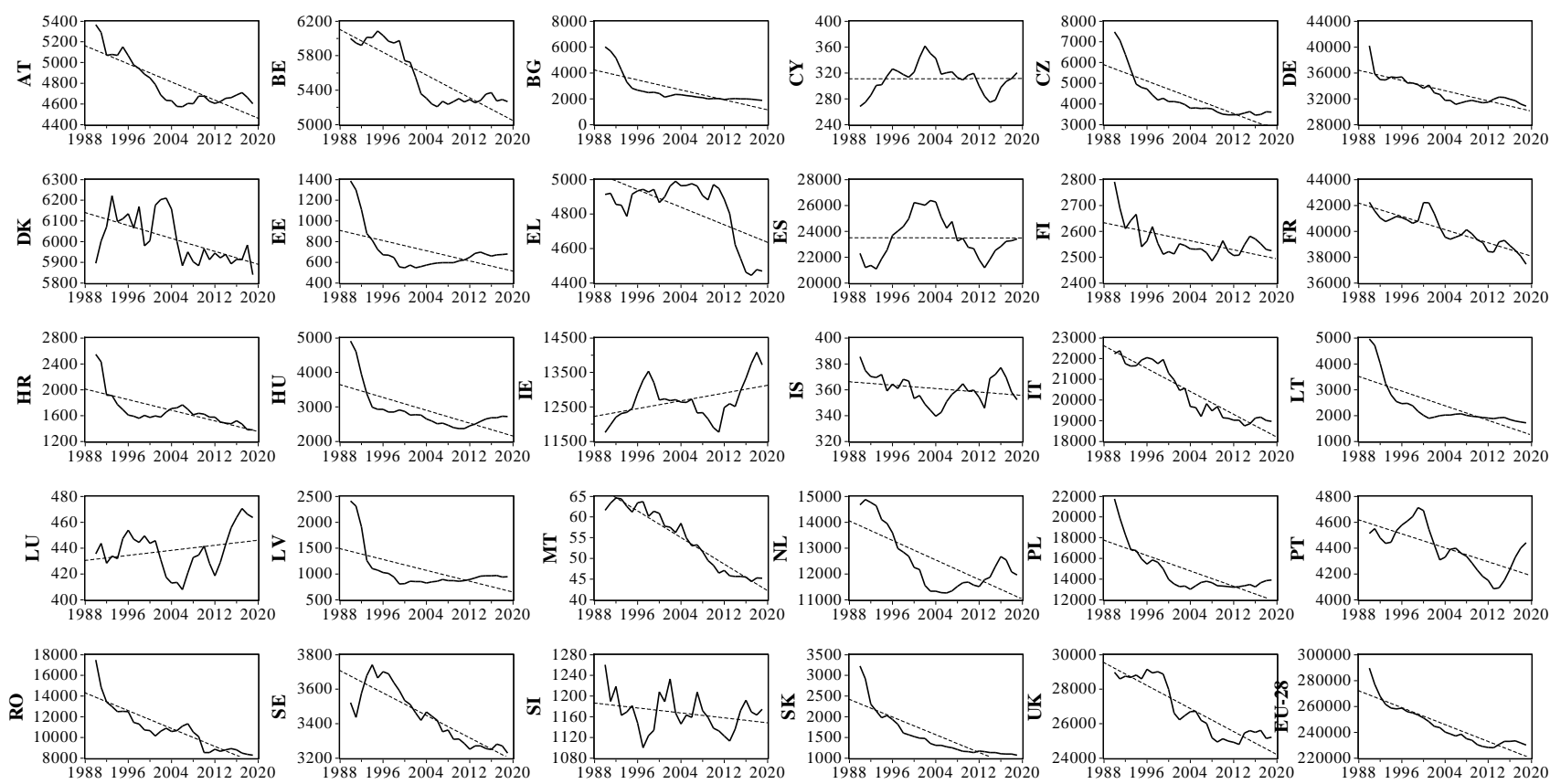

Figure 4. Time evolution of $\mathrm{N}_{2} \mathrm{O}$ emissions between 1990 and 2019 within EU-28 (agricultural sector).

\subsection{Multivariate Analysis of GHGs Emissions in 1990 and 2019}

The total variance explained was $99 \%$ for the data of 1990 and $98 \%$ for 2019 . Goodnessof-fit analysis also indicated a very good fit, with RMSRs of 0.01 for both years. Two PCs were confirmed by the RMSRs; PC1 correlated with the $\mathrm{N}_{2} \mathrm{O}$ and $\mathrm{CH}_{4}$ emissions, explaining 58\% (in 1990) and 51\% (in 2019) of the variance, while PC2 correlated with $\mathrm{CO}_{2}$, and explained 41\% (in 1990) and 46\% (in 2019) of the variance. Consequently, PC2 involved only one variable, $\mathrm{CO}_{2}$, while $\mathrm{PC} 1$ followed the state of $\mathrm{N}_{2} \mathrm{O}$ and $\mathrm{CH}_{4}$ on the same axis.

Most countries formed a compact group in both years in the lower section of the diagram, regarding $\mathrm{N}_{2} \mathrm{O}$ and $\mathrm{CH}_{4}$, and with a larger variance in $\mathrm{CO}_{2}$. There were also outlier countries (having scores larger than two) regarding the lower or higher GHG emissions (Figure 5). In 1990, DE, FR, the UK, and PL represented the highest emissions of $\mathrm{N}_{2} \mathrm{O}$ and $\mathrm{CH}_{4}$, and $\mathrm{CZ}, \mathrm{PL}$, and $\mathrm{DE}$ had larger emissions of $\mathrm{CO}_{2}$. The lowest $\mathrm{CO}_{2}$ belonged to $\mathrm{RO}, \mathrm{FR}, \mathrm{IT}$, and ES. The scores were mainly between -1 and 1 regarding the $\mathrm{CO}_{2}$; thus, the variance was smaller than what was observed in PC2 $\left(\mathrm{N}_{2} \mathrm{O}\right.$ and $\left.\mathrm{CH}_{4}\right)$. There were changes in the pattern in 2019 , but the most important ones were observed in the lowest and largest values. The positions regarding PC1 (i.e., $\mathrm{N}_{2} \mathrm{O}$ and $\mathrm{CH}_{4}$ ) did not change, but the $\mathrm{CO}_{2}$ emission decreased in PL and CZ, and increased in the UK, DE, and FR. The lowest $\mathrm{CO}_{2}$-emitting countries were ES, IT, and NL.

There were no significant differences regarding PC1 in 1990 (Kruskal-Wallis H: 8.334, $p=0.138$ ) and in 2019 (Kruskal-Wallis H: 6.654, $p=0.254$ ). Similarly, there was no significant difference in $\mathrm{CO}_{2}$ emissions in 1990 (Kruskal-Wallis H: 9.973, $p=0.076$ ) and in 2019 (Kruskal-Wallis H: 10.59, $p=0.052$ ). Accordingly, the spatial distribution of the countries did not discriminate the emissions. 


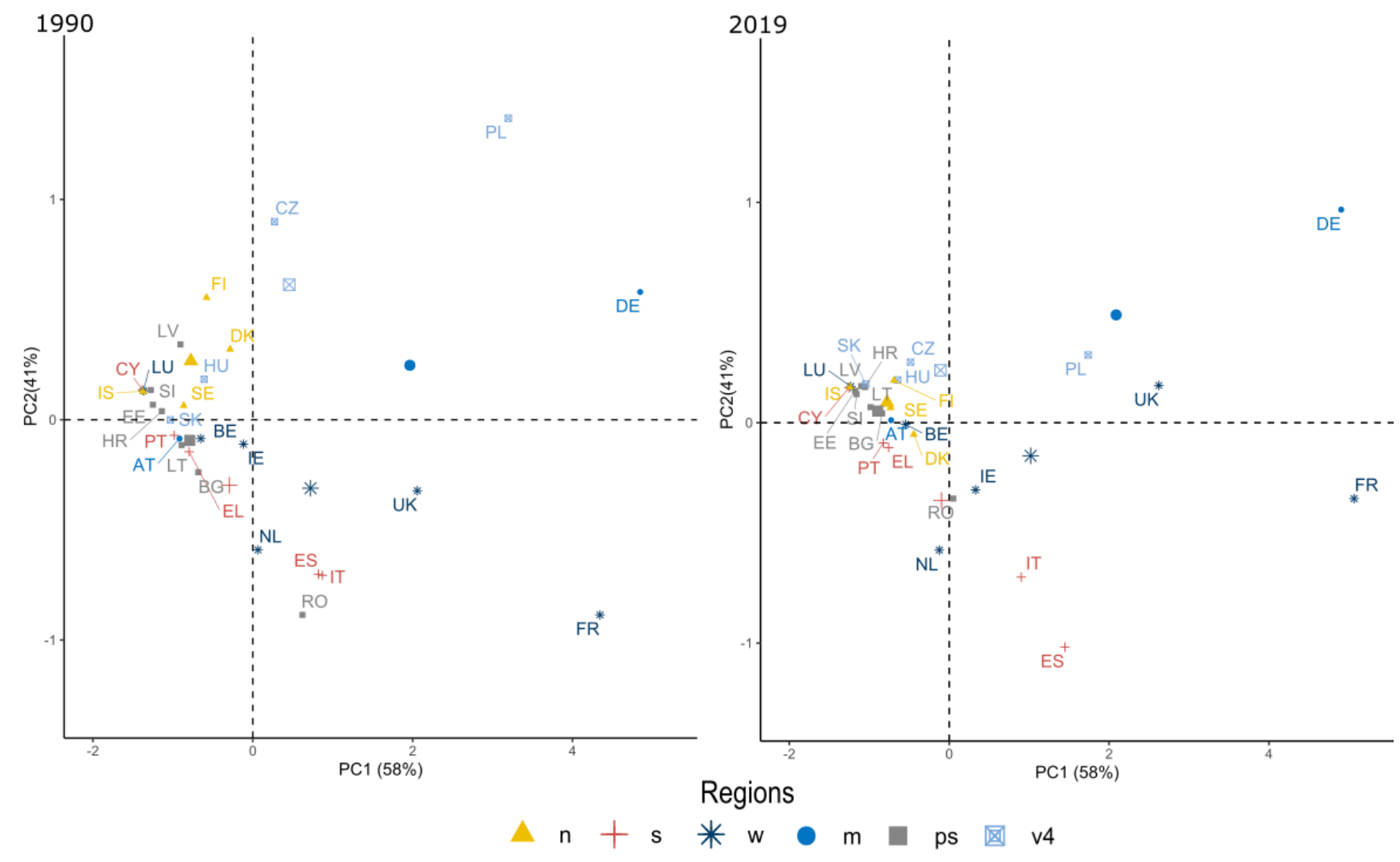

Figure 5. Ordination diagram of GHG emissions $\left(\mathrm{N}_{2} \mathrm{O}, \mathrm{CH}_{4}, \mathrm{CO}_{2}\right)$ in 1990 and 2019 within EU-28 (agricultural sector; $\mathrm{n}$ : Northern Europe, s: Southern Europe, w: Western Europe, m: Middle Europe, ps: post-socialist countries, v4: Visegrad 4 countries; large symbols: group centroids).

Cluster analysis, focusing on the positive and negative changes, revealed that the difference was the most discriminative in the case of Iceland, due to its high increase in $\mathrm{CO}_{2}$ emissions. Other clusters were only partly formed by their location (e.g., southern or western), and the differences were relatively smaller than those observed in Iceland. As Iceland formed a unique cluster in itself, we did not involve it in the statistical evaluation. Cluster 1 (C1) was formed by purely post-socialist countries, but all the other clusters were a mixture of different locations and historic heritage (Figure 6). This approach maximized the variance among the countries; thus, the clusters reflected similarity in the changes (Figure 7).

The $\mathrm{C} 1$ cluster contained the countries that had the largest negative change, i.e., these countries made the largest progress in reducing GHG emissions. The countries of the $\mathrm{C} 2$ cluster gained relevant results on decreasing $\mathrm{CO}_{2}$ and $\mathrm{CH}_{4}$, and the $\mathrm{N}_{2} \mathrm{O}$ emissions also decreased, but by a smaller measure. In the $\mathrm{C} 3$ cluster, the countries only reached a small decrease in each GHG, and a limited increase was observed for $\mathrm{CO}_{2}$. In both the $\mathrm{C} 4$ and $\mathrm{C} 5$ clusters, the $\mathrm{CO}_{2}$ emissions increased, while the $\mathrm{N}_{2} \mathrm{O}$ and $\mathrm{CH}_{4}$ emissions decreased; the difference between the two clusters was that in $\mathrm{C} 5$, the decrease was smaller. 


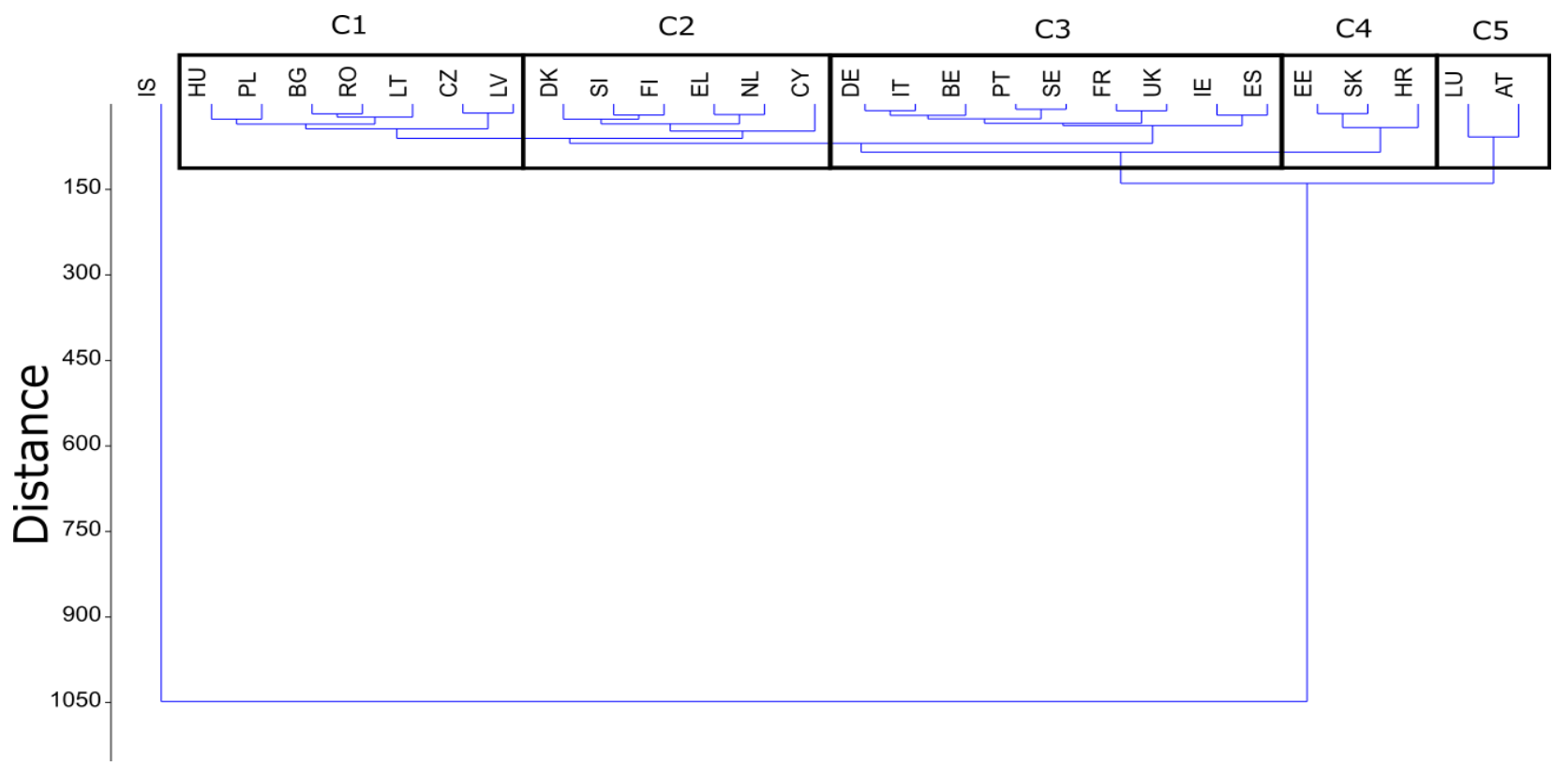

Figure 6. Clusters of GHG emission change (input: emissions of $\mathrm{CO}_{2}, \mathrm{CH}_{4}$ and $\mathrm{N}_{2} \mathrm{O}$ in 2019 were divided by the emission of 1990, expressed in \%, C1-C5: clusters).

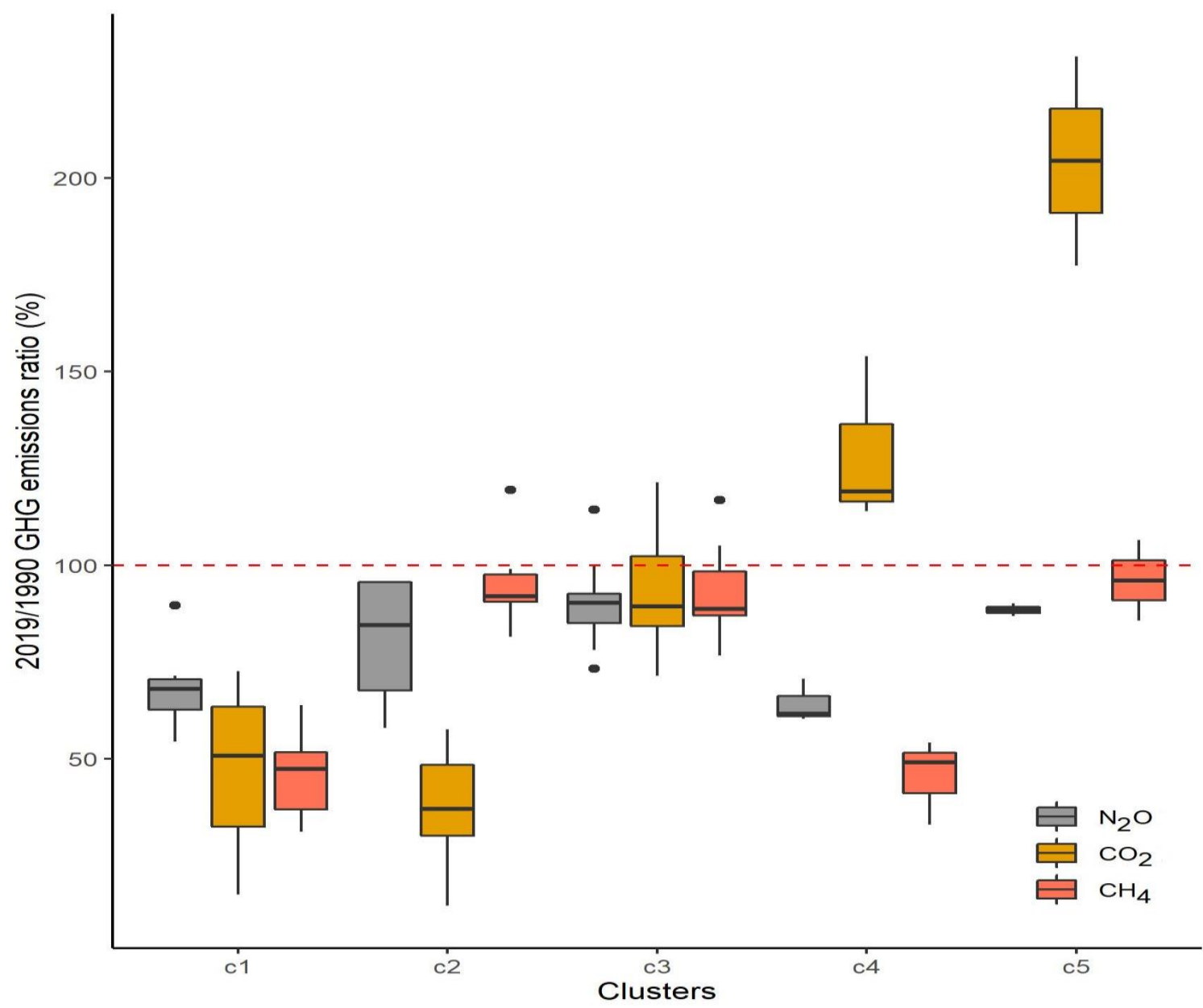

Figure 7. Ratio of GHG emissions 2019/1990 (dashed line indicates no change, below the line changes were negative, above the line they were positive; C1-C5: clusters of countries indicated by Figure 6. 


\section{Discussion}

In general, the trend of GHG emissions from the agricultural sector in EU countries was negative during 1990-2019, except for some countries, such as Estonia, Ireland, and Latvia, which displayed a slight increase from 3-5.6 thousand tons/year. Iceland and Hungary both exhibited insignificant increases. A significant increase in GHG emissions was exhibited by Spain (Figure 1), with a significant increase in $\mathrm{N}_{2} \mathrm{O}$ emissions (Figure 4). In fact, more than $72 \%$ of the Spanish land was used for agricultural practices and forestry, while $19 \%$ was used for meadows, which accelerated the GHG emissions from this sector [48,49]. Nonetheless, $11 \%$ of the total emissions in Spain originated from the agricultural sector [50]. The increase in GHG emissions in Spain, between 1990 and 2019, could be attributed to the lack of clear national strategies for minimizing and mitigating GHG emissions from the Spanish agricultural sector [51] (Table 2). This was exacerbated by the highly intensive agricultural production per capital and technological advancements in the agricultural sector in Spain in the recent decades [52]. The significant positive trend of GHG emissions was mainly dependent on the increase in $\mathrm{N}_{2} \mathrm{O}$ emissions from 1990 to 2019, with an overall trend of 52.44 thousand tons/year. This trend may be because of the mismanagement of soil fertilization, agrochemicals. Livestock manure was the main cause of $\mathrm{N}_{2} \mathrm{O}$ emissions, eutrophication of water courses, and atmosphere acidification. Similar conclusions have been reported by Albiac et al. [52] and other workers [53,54]. Magrama [55] noted that the overdose of $\mathrm{N}$ fertilizer, along with the neglect of livestock manure, added more than $780.000 \mathrm{tN}$ of fertilizer to the soil, leading to severe environmental pollution. Nevertheless, the mean annual increase in $\mathrm{CH}_{4}$ and $\mathrm{CO}_{2}$ emissions during the period of this study showed much lower values of 9.10 and 1.69 thousand tons/year, respectively. Other countries, such as Italy, the Netherlands, the UK, among others, manifested a significant decline in the total GHG emissions.

In Italy, only 7.1\% of the GHG emissions originated from the agriculture sector in 2016. The decline in GHG emissions can be attributed to a decrease in the number of animals, especially the dairy cattle heads from 1990 to 2016, which resulted in a decline of about $40 \%$ [56]; this may have contributed to the negative trend of $\mathrm{CH}_{4}$ emissions (Table 2 and Figure 3). Also, the $\mathrm{CH}_{4}$ and $\mathrm{N}_{2} \mathrm{O}$ from manure management decreased with the decline in the number of animals during the studied period. The more efficient manure management system may have also contributed to the reduction in $\mathrm{N}_{2} \mathrm{O}$ [56]. The $\mathrm{CH}_{4}$ emissions from rice cultivation have also decreased, according to the revised $\mathrm{CH}_{4}$ daily $\mathrm{EF}$ measurements in Italian rice fields $[57,58]$, considering the different agronomic practices between the different cultivars [59,60], and the different irrigation regimes [61]. The $\mathrm{N}_{2} \mathrm{O}$ emissions from managed soils declined from $29.72 \mathrm{Gg}\left(80.6 \%\right.$ of $\mathrm{N}_{2} \mathrm{O}$ emissions for the agriculture sector) in 1999 to $23.99 \mathrm{Gg}(78.2 \%)$ in 2016, where this decline agreed with Table 2 and Figure 4. The decline in the $\mathrm{N}_{2} \mathrm{O}$ emissions from managed soils may be because of a reduction in the use of inorganic and organic fertilizers, which was about 25\% from 1990 until 2016 [56]. Romano et al. [56] reported that the application of carbonate for decreasing soil acidity is one of the main sources for $\mathrm{CO}_{2}$ emissions. In this context, the liming process in Italy was responsible for $2.3 \%$ (2016) of the total $\mathrm{CO}_{2}$ emissions from the agricultural sector [56].

The agricultural sector in the UK accounted for 10\% (2018) of the GHG emissions [62], where livestock and manure accounted for $56 \%$ of the emissions, synthetic fertilizers accounted for $31 \%$, and fuel and machinery accounted for $12 \%$ [62]. There was a significant decline in $\mathrm{CH}_{4}$ and $\mathrm{N}_{2} \mathrm{O}$ emissions in the UK during the studied period, with values of -166 thousand tons/year, $p<0.05$, and -115.55 thousand tons/year, $p<0.05$, respectively; this resulted in a decline in the total GHG emissions, with a trend of -266.40 thousand tons/year, $p<0.05$ (Table 2). Similarly, Nair et al. [63] and NFS [64] reported that, overall, the GHG emissions from agriculture in the UK have decreased by 16\% from 1990 to 2018 . Ortiz et al. [62] mentioned three factors that led to a significant GHG emission decrease from the agricultural sector. The factors are as follows: (1) adaptation of new technology in the agricultural sector, (2) national policies, and (3) changing the incentives model, 
which reduced the number of ruminants to meet the EU-CAP (Common Agricultural Policy). The UK have launched a national framework for evaluating the annual reduction in GHG emissions since 2012. This framework covers ten indictors, including mitigation and adaptation methods, farmer knowledge and behavior, and emission per product [65]. It is good to mention here that a large amount of research in the UK was focused on the improvement in the agricultural GHG inventory [65]. The livestock population in the UK reduced by $19.8 \%$ from 1990 to 2018 , while only the dairy cattle category also decreased by $33.6 \%$. The application of $\mathrm{N}$ fertilizer had been dropped by permanent grasslands, which represented almost half of the area of the UK's major crop area, with $55.6 \%$ from 1990 to 2018, while the other crops have been fluctuating between declining, such as by grass leys, oilseed rape, and potatoes, with $41 \%, 19 \%$, and $27.2 \%$, respectively; stabilizing, such as by wheat; and increasing in $\mathrm{N}$ fertilizer, such as by Spring and Winter barely, with $15.6 \%$ and $10 \%$, respectively [66].

Studies indicate that liming is a major contributor to $\mathrm{CO}_{2}$ emissions in the agricultural sector. The contribution of the agricultural sector to GHG emissions in the Netherlands was about $9.7 \%$ in 2019 . There was a reduction in the application of lime, which also caused a reduction in $\mathrm{CO}_{2}$ emissions during 1990-2008 and 2016-2019 in the Netherlands, although there was a slight increase in emissions in 2009. The reduction in liming resulted in the decline of $\mathrm{CO}_{2}$ emissions, by $80.9 \%$, from 1990 to 2019 (0.18-0.03 $\mathrm{Tg} \mathrm{CO}_{2}$ eq), while the $\mathrm{CO}_{2}$ emissions from urea application increased from 0.002 to $0.045 \mathrm{Tg} \mathrm{CO}_{2}$ eq in the same period [67]. This behavior explained the results of the $\mathrm{CO}_{2}$ emissions of NL (Figures 2 and 3, and Table 2). The trend of methane during the studied period decreased because of a reduction in the application of mature dairy cattle, where the $\mathrm{CH}_{4}$ emissions of enteric fermentation and manure management decreased from 1990 to 2005, increased from 2007 to 2016, then start to decrease again [67]. The significant negative trend of $\mathrm{N}_{2} \mathrm{O}$ emissions in NL (Figure 4) is explained by the decrease in organic and inorganic $\mathrm{N}$ fertilizer application, the decrease in animal numbers, and the decrease in animal production on pasture, from 1990 to 2010, and, after 2010, the decline in $\mathrm{N}_{2} \mathrm{O}$ emissions was stabilized at $44.8 \%$ (8.7-4.8 $\mathrm{Tg} \mathrm{CO}_{2}$ eq). This is similar to the decrease in $\mathrm{N}_{2} \mathrm{O}$ from the agriculture soil reported by Ruyssenaars et al. [67].

For Romania, a number of measures have contributed to the reduction in GHG emissions, such as minimizing the amount of synthetic nitrogen fertilizer, decreasing the number of livestock, and reducing the area under rice cultivation [68]. The Romanian agricultural sector contributed $18.98 \%$ (2015) to the total GHG emissions [68]. Compared to 1989, the reduction in GHG emissions reached $78.93 \%$ by liming, $72.98 \%$ by rice cultivation, $61.86 \%$ by manure management, $49.20 \%$ by enteric fermentation, $48.48 \%$ by agricultural soils, $46.34 \%$ by urea application, and $12.84 \%$ by the field burning of agricultural residues [68] These findings agreed with the negative trend of Romania in Table 2 and Figures 1-4. Table 2 shows that the negative trend of $\mathrm{CH}_{4}$ was the highest, -187.77 thousand tons/year, followed by $\mathrm{N}_{2} \mathrm{O}$ emissions with a negative trend, -72.44 thousand tons/year.

The total share of GHG emissions from agriculture in 2017 in Poland was 7.16\% [69]. However, Poland showed a significant decline in the agricultural GHG emissions from 1990 to 2019, with a trend of -216.02 thousand tons/year $(p<0.05)$, which was categorized into -33.94 thousand tons/year $(p<0.05),-137.11$ thousand tons/year $(p<0.05)$, and -36.94 thousand tons/year $(p<0.05)$ for the $\mathrm{CO}_{2}, \mathrm{CH}_{4}$, and $\mathrm{N}_{2} \mathrm{O}$ emissions (Table 2), respectively. Poland's National Inventory Report [69] stated that the decline in $\mathrm{CH}_{4}$ emissions was due to the dramatic decrease in the livestock population after 1989, especially for the dairy cattle population that decreased by almost 50\% from 1990 to 2017. This decline in the livestock population decreased the $\mathrm{CH}_{4}$ emissions for enteric fermentation and manure management. As well as this, the $\mathrm{N}_{2} \mathrm{O}$ emissions from manure management dropped by $31 \%$ from 1988 to 2017, also depending on the diminishing livestock population. $\mathrm{N}_{2} \mathrm{O}$ emissions mainly come from the agriculture soil, which was significantly decreased from 1988 to 2017, by 21\%. However, nitrogen fertilization accounted for $47 \%$ of direct $\mathrm{N}_{2} \mathrm{O}$ emission (2017). Piwowar [70] explained that the liming process and carbonate usage 
were balanced from 2000 to 2004, and were relatively low later on. The $\mathrm{CO}_{2}$ emissions from lime, dolomite and urea utilization were significantly decreased from 1988 to 2017 [69].

French agriculture GHG emissions contributed $16.8 \%$ of the total GHG emissions in 2019 [71]. France accounts for $25 \%$ of the livestock in Europe, and $40 \%$ of the agricultural land in France is used for cereal production, making France the largest producer of cereal in the EU [72]. The large proportion of livestock and cereal production in France also implies that France will account for a large part of the GHG emissions, and will have a difficult challenge in reducing GHGs. However, there was a significant decline in $\mathrm{CH}_{4}$ emissions resulting from livestock (Table 2). The National Inventory Report for France [71] noted that a $34 \%$ decline in the dairy cattle population resulted in a $13 \%$ decrease in enteric fermentation emission from 1990 to 2019. An increase in the number of pig herds has been linked to an increase in manure management and a $7 \%$ increase in $\mathrm{CH}_{4}$ emissions over the period 1990-2019. However, other parameters, such as the increase in manure management systems in the form of slurry, are contributing inversely to this trend. Rice cultivation is also a major contributor to $\mathrm{CH}_{4}$ emissions. The area under rice cultivation in 1990 was 22,458 ha. This increased to 34,405 ha in 1994 , but has declined to 15,100 ha in 2019 . A decrease in the area under rice cultivation results in a decrease in rice cultivation-induced $\mathrm{CH}_{4}$ emissions. Table 2 shows that the $\mathrm{N}_{2} \mathrm{O}$ emissions also decreased significantly during 1990-2019. The National Inventory Report for France [71] indicated a decrease in $\mathrm{N}_{2} \mathrm{O}$ emissions by minimizing the use of mineral nitrogen fertilizers, which reduced the $\mathrm{N}_{2} \mathrm{O}$ emissions by $-16 \%$ (1990-2019), and decreasing the cattle herds, resulting in a reduction in both the nitrogen excreted in the pasture and the organic nitrogen to be applied, leading to a $12 \%$ decline in $\mathrm{N}_{2} \mathrm{O}$ emissions from 1990 to 2019 . The total $\mathrm{N}_{2} \mathrm{O}$ emissions from agricultural soils decreased by $-9 \%$ over the period 1990-2019 (Table 2).

In Germany, the agriculture sector was responsible for $7.6 \%$ of the total GHG emissions in 2019 [73]. The total GHG emissions from the agricultural sector decreased by $19.2 \%$ in the period 1990-2021 [74]. This decline is consistent with the negative trend in Table 2 $(-166.74$ thousand tons/year, $p<0.05)$, which mainly depends on the $\mathrm{CH}_{4}$ emissions trend that revealed -177.53 thousand tons/year $(p<0.05)$ (Table 2). As mentioned before, the $\mathrm{CH}_{4}$ emissions come from enteric fermentation and manure management, and both rely the most on the population of animals, especially the dairy cattle, and pig for manure management. The German NIR [75] reported that, from 1990 to 2019, the decline in the animal population was almost $37 \%, 42 \%, 18.5 \%$, and $41.6 \%$ for the dairy cattle, swine, sheep, and goats, respectively. This notable decline in the animal population leads to a decrease in $\mathrm{CH}_{4}$ emissions, by $27.7 \%$ and $21.3 \%$ for enteric fermentation and manure management, respectively [74] (Table 2 and Figure 3). The $\mathrm{N}_{2} \mathrm{O}$ emissions include manure management, energy crops (from digester and storage of digestate from the anaerobic digestion of energy crops, and include both $\mathrm{CH}_{4}$ and $\mathrm{N}_{2} \mathrm{O}$ emissions), and agricultural soil. In regards to the emissions from energy crops $\left(\mathrm{CH}_{4}\right.$ and $\left.\mathrm{N}_{2} \mathrm{O}\right)$, which presented the smallest share of the total agricultural GHG emissions (2.5\% in 2019), they increased from zero in 1990 to $1573 \mathrm{Tg} \mathrm{CO}_{2}$ eq in 2019, with a gradual utilization of energy crops since 1991 . The $\mathrm{N}_{2} \mathrm{O}$ emissions decreased by $18.9 \%$ for manure management and $15.3 \%$ for agricultural soil. The smaller dwindling of $\mathrm{N}_{2} \mathrm{O}$ emissions from 1990 to 2019 may be attributed to variation in its components' behavior (decrease in mineral fertilizer $\mathrm{N}$ quantities by $35 \%$, decrease in manure $\mathrm{N}$ quantities, including energy crops, by $18.6 \%$, increase in crop residues $\mathrm{N}$ quantities by $16 \%$, and the relatively unchanged indirect soil emissions) [74,75]. In contrast, our results indicate a positive, but not significant, trend of $\mathrm{N}_{2} \mathrm{O}$ (Table 2). The reasonable cause of that could be the increase in the applied $\mathrm{N}$ fertilization quantities between 2014 and 2016. The $\mathrm{CO}_{2}$ emissions trend exhibited an increase, with a positive trend (16.66 thousand tons/year $(p>0.05)$ ) (Table 2, Figure 2). Similar results were reported by the German NIR [75], which highlighted a $10.68 \%$ and $8.8 \%$ increase in the application of limestone and urea, respectively, and a decrease in the application of dolomite and calcium ammonium nitrate ( $84.5 \%$ and $61.6 \%$, respectively). This resulted in a total increase in $\mathrm{CO}_{2}$ emission from 1990 to 2019, by 11.6\% [74]. 
The highest share of GHG emissions in the agricultural sector is presented by the $\mathrm{CH}_{4}$ and $\mathrm{N}_{2} \mathrm{O}$ emissions, accounting for more than $90 \%$ of the total GHG emissions. This majority share explained the clear proximity of the $\mathrm{CH}_{4}$ and $\mathrm{N}_{2} \mathrm{O}$ emission values of the contributing countries to the PC1 (Figure 5), where $\mathrm{CH}_{4}$ and $\mathrm{N}_{2} \mathrm{O}$ emissions, which are the closest components to PC1, best approximate the total GHG emissions. Nevertheless, the $\mathrm{CO}_{2}$ emission values with a lower share of GHG emissions, and sometimes with opposite behavior to the total GHG emission values, were close to PC2. However, analysis of the spatial pattern, or even the historical heritage (post-socialist shared heritage on the agriculture, with the transformation from large agricultural co-operations to private farming), did not reveal any result. There were exceptions in each group; thus, the differences were not significant in the change between 1990 and 2019. The biplots pointed out countries that had increasing or decreasing changes during the 29 years. Furthermore, cluster analysis was the best method to show the country groups of similar changes, but, in this case, we involved the ratio of the change in the GHG emissions between the earliest and latest dates, dividing the data of 2019/1990. This approach was an efficient tool to identify the countries that have similar gains in GHG emission reduction, or in pointing out the ones that have issues in reaching the goals.

Iceland formed a sole cluster, but we have to highlight that the cause of this was the $1128 \%$ surplus in the $\mathrm{CO}_{2}$ emissions from agricultural sources. This seems to be a large increase, but in 1990, the initial emissions were only 0.52 thousand tons, the smallest in the EU countries; even Luxembourg and Cyprus could approach it (with 6.3 and 1.8 thousand tons). In 2019, the $\mathrm{CO}_{2}$ emissions of Iceland increased to 5.87 thousand tons, which was the second lowest in the EU, and Cyprus was the first, with 0.22 thousand tons in this year. In 2021, the world's first $\mathrm{CO}_{2}$ removal plant started operating in Iceland, which will remove $4000 \mathrm{t}$ of $\mathrm{CO}_{2}$ a year [76]. Austria and Luxembourg formed the cluster, both having the worst performance, but the increase should also be evaluated carefully; Luxembourg is still third in the ranks of $\mathrm{CO}_{2}$ emissions in the EU. Accordingly, the countries that had the smallest emissions in 1990 can appear as inefficient ones in $\mathrm{CO}_{2}$ reduction, but there are lot of components of these numbers. Besides local food production, transportation and even food import can also count, and can have direct consequences on the emissions too [77]. Although the population did not increase in the European countries, globalization can generate demands and, therefore, food or agricultural product import and export. In the case of Iceland, the food product import was USD 268,000 in 1990 and USD 1,266,638 in 2019; therefore, the increase was almost five times as large [78].

Climate change mitigation, for finding more efficient farming, is one of the global challenges in the EU. The utilization of optimal agricultural practice management, provided by convenient technologies, assists by not only reducing the GHG emissions, but also promoting agricultural productivity and income [79]. Precision agriculture can achieve this, where precision agriculture based on utilizing digital techniques can aid in monitoring and optimizing agriculture production processes at different field scales [80]. Precision agriculture supports the optimization of field management based on the actual crop needs; for example, using sensors to identify the specific area in field that needs a particular treatment, such as irrigation, fertilizers, insecticides, and herbicides [81]. However, promoting precision agriculture in Europe could be one of the solutions for mitigating climate change across the EU-28.

In this research, the trend of GHG emissions from agricultural sectors across the EU-28 was analyzed between 1990 and 2019, accompanied by multivariate analysis. The results only highlighted the GHG trend, with no further information about the GHGs origins (soil, fertilization, livestock, food production), which is one of the drawbacks of this research. On the other hand, this study did not investigate the relationship between GHGs and GDP, where GDP can play an important role in GHG emissions, and could help in discriminating and categorizing European countries regarding their emissions. However, future steps will employ the environmental Kuznets curve (EKC) for exploring the relationship between 
economic growth and environmental degradation. Previous studies also reveal that, in the long run, economic growth could lead to the reduction in atmospheric pollution $[2,82]$.

\section{Conclusions}

Since the release of the Paris Agreement in 2015, the EU have strived to reduce GHG emissions from all sectors to achieve carbon neutrality (zero emission). Thus, a package of policies and strategies was released in order to achieve this aim. To reach this ambitious goal by 2050, GHG emissions need to be evaluated on a sectorial level (i.e., industry, agriculture, energy) to provide decision makers with a full overview of the changes, and the efficiency of mitigation and adaptation strategies.

In this research, the GHG emissions from the agricultural sector within the EU-28, from 1990 to 2019, was analyzed by using the MK test and multivariate approach. The analysis revealed that most of the EU-28 countries exhibited a significant reduction in GHG emissions (1990-2019). The highest reduction in the total GHG emissions was recorded in Italy $(-282.61$ thousand tons/year, $p<0.05)$, followed by the United Kingdom $(-266.40$ thousand tons / year, $p<0.05)$, and the Netherlands $(-262.91$ thousand tons / year, $p<0.05)$. Similarly, the $\mathrm{CH}_{4}$ and $\mathrm{N}_{2} \mathrm{O}$ emissions exhibited a negative emission trend from most of the EU-28 countries. However, a positive $\mathrm{CO}_{2}$ emissions trend from the agricultural sector, between 1990 and 2019, was recorded. Nonetheless, the accumulation of $\mathrm{CO}_{2}$ emissions from all the EU-28 countries depicted a non-significant negative trend ( -9.61 thousand tons/year). Interestingly, the multivariate analysis approach indicates changes in the pattern of GHG emissions between 1990 and 2019. In 1990, DE, FR, the UK, and PL represented the highest emissions of $\mathrm{N}_{2} \mathrm{O}$ and $\mathrm{CH}_{4}$; where $\mathrm{CZ}, \mathrm{PL}$, and DE had larger emissions of $\mathrm{CO}_{2}$. In 2019, the patterns were changed, in terms of the lowest and largest values.

The findings of this study highlight the need for policy makers in the European Union to evaluate the strategies for mitigating $\mathrm{CO}_{2}$ emissions, and underline the need to formulate new policies for reducing $\mathrm{CO}_{2}$ emissions from the agricultural sector. However, future studies should focus on analyzing the relationship between GHG emissions from the agricultural sector and environmental degradation, through the application of environmental Kuznets curve hypothesis.

Author Contributions: Conceptualization, S.M. and E.H.; methodology, S.M. and S.S; writingoriginal draft preparation, S.M., A.E., G.A., O.H. and M.M.; writing-review and editing, B.B., A.A., and G.O.E.; supervision, S.S. and E.H.; funding acquisition, B.B., and A.A. All authors have read and agreed to the published version of the manuscript.

Funding: This research was supported by RESEARCHERS SUPPORTING PROJECT, grant number RSP-2021/296, King Saud University, Riyadh, Saudi Arabia. Szabo S. was supported by the Project TKP2020-IKA-04 (National Research, Development and Innovation Fund of Hungary, financed under the 2020-4.1.1-TKP2020) funding scheme.

Institutional Review Board Statement: Not applicable.

Informed Consent Statement: Not applicable.

Data Availability Statement: Original data available on the EEA website.

Acknowledgments: The authors are grateful to EEA team for providing data used in this study. Authors would like to thank Debrecen University (Hungary) and King Saud University for their unlimited support.

Conflicts of Interest: The authors declare no conflict of interest.

\section{References}

1. Dale, A.; Robinson, J.; King, L.; Burch, S.; Newell, R.; Shaw, A.; Jost, F. Meeting the climate change challenge: Local government climate action in British Columbia, Canada. Clim. Policy 2020, 20, 866-880. [CrossRef]

2. Mohammed, S.; Gill, A.R.; Alsafadi, K.; Hijazi, O.; Yadav, K.K.; Khan, A.H.; Harsanyi, E. An overview of greenhouse gases emissions in Hungary. J. Clean. Prod. 2021, 127865. [CrossRef] 
3. Shakoor, A.; Ashraf, F.; Shakoor, S.; Mustafa, A.; Rehman, A.; Altaf, M.M. Biogeochemical transformation of greenhouse gas emissions from terrestrial to atmospheric environment and potential feedback to climate forcing. Environ. Sci. Pollut. Res. 2020, 27, 38513-38536. [CrossRef]

4. IPCC (Intergovernmental Panel on Climate Change). Climate Change 2014: Mitigation of Climate Change. Working Group III Contribution to The IPCC Fifth Assessment Report; Cambridge University Press: Cambridge, UK, 2014; Available online: www.ipcc. ch/report/ar5/wg3 (accessed on 3 March 2021).

5. WRI (World Resources Institute). Climate Watch Historical GHGE. Available online: www.climatewatchdata.org/ghg-emissions. (accessed on 3 March 2021).

6. FAO (Food and Agriculture Organization). FAOSTAT Emissions Database-Land Use Indicators. Available online: www.fao.org/ faostat/en/\#data/EL. (accessed on 24 March 2021).

7. IPCC (Intergovernmental Panel on Climate Change). Climate Change: The Physical Science Basis. Working Group I Contribution to the IPCC Fifth Assessment Report; Cambridge University Press: Cambridge, UK, 2013; Available online: www.ipcc.ch/report/ar5/wg1 (accessed on 3 March 2021).

8. Herzog, T. World Greenhouse Gas Emissions in 2005. World Resources Institute 2009, 1-7. Available online: https:/ /www.wri. org/research/world-greenhouse-gas-emissions-2005 (accessed on 5 October 2021).

9. Tubiello, F.N.; Salvatore, M.; Rossi, S.; Ferrara, A.; Fitton, N.; Smith, P. The FAOSTAT database of greenhouse gas emissions from agriculture. Environ. Res. Lett. 2013, 8, 015009. [CrossRef]

10. Tongwane, M.I.; Moeletsi, M.E. A review of greenhouse gas emissions from the agriculture sector in Africa. Agric. Syst. 2018, 166, 124-134. [CrossRef]

11. Tian, H.; Xu, R.; Canadell, J.G.; Thompson, R.L.; Winiwarter, W.; Suntharalingam, P.; Davidson, E.A.; Ciais, P.; Jackson, R.B.; Janssens-Maenhout, G.; et al. A comprehensive quantification of global nitrous oxide sources and sinks. Nature 2020, 586, 248-256. [CrossRef]

12. Folberth, C.; Khabarov, N.; Balkovič, J.; Skalský, R.; Visconti, P.; Ciais, P.; Janssens, I.A.; Peñuelas, J.; Obersteiner, M. The global cropland-sparing potential of high-yield farming. Nat. Sustain. 2020, 3, 281-289. [CrossRef]

13. Zafeiriou, E.; Mallidis, I.; Galanopoulos, K.; Arabatzis, G. Greenhouse Gas Emissions and Economic Performance in EU Agriculture: An Empirical Study in a Non-Linear Framework. Sustainability 2018, 10, 3837. [CrossRef]

14. Statista: Emissions in the EU—Statistics \& Facts. Available online: https://www.statista.com/topics/4958/emissions-in-theeuropean-union/ (accessed on 25 September 2021).

15. Gołasa, P.; Wysokiński, M.; Bieńkowska-Gołasa, W.; Gradziuk, P.; Golonko, M.; Gradziuk, B.; Siedlecka, A.; Gromada, A. Sources of Greenhouse Gas Emissions in Agriculture, with Particular Emphasis on Emissions from Energy Used. Energies 2021, 14, 3784. [CrossRef]

16. Rokicki, T.; Perkowska, A.; Klepacki, B.; Bórawski, P.; Bełdycka-Bórawska, A.; Michalski, K. Changes in Energy Consumption in Agriculture in the EU Countries. Energies 2021, 14, 1570. [CrossRef]

17. Eurostat. Final Energy Consumption by Sector and Fuel. 2014. Available online: https://www.eea.europa.eu/data-and-maps/ indicators / final-energy-consumption-by-sector-9/assessment-1\#tab-related-briefings (accessed on 30 June 2021).

18. Agri-Environmental Indicator-Energy Use. Available online: https:/ / ec.europa.eu/eurostat/statistics-explained/index.php/ Agri-environmental_indicator_-_energy_use (accessed on 30 June 2021).

19. Li, T.; Baležentis, T.; Makutènienè, D.; Streimikiene, D.; Kriščiukaitienè, I. Energy-related $\mathrm{CO}_{2}$ emission in European Union agriculture: Driving forces and possibilities for reduction. Appl. Energy 2016, 180, 682-694. [CrossRef]

20. Bajan, B.; Łukasiewicz, J.; Mrówczyńska-Kamińska, A. Energy Consumption and Its Structures in Food Production Systems of the Visegrad Group Countries Compared with EU-15 Countries. Energies 2021, 14, 3945. [CrossRef]

21. Masi, M.; Vecchio, Y.; Pauselli, G.; Di Pasquale, J.; Adinolfi, F. A Typological Classification for Assessing Farm Sustainability in the Italian Bovine Dairy Sector. Sustainability 2021, 13, 7097. [CrossRef]

22. European Commission. The Post-2020 Common Agricultural Policy: Environmental Benefits and Simplification. 2019. Available online: https: / / ec.europa.eu/info/sites/info/files/food-farming-fisheries/key_policies/documents / cap-post-2020-environbenefits-simplification_en.pdf (accessed on 18 June 2020).

23. Malinovský, V. System Macromodel of Agricultural Building with Aim to Energy Consumption Minimization. Agris on-line Pap. Econ. Informatics 2018, 10, 25-35. [CrossRef]

24. Piwowar, A. Challenges associated with environmental protection in rural areas of Poland: Empirical studies' results. Econ. Sociol. 2020, 13, 217-229. [CrossRef] [PubMed]

25. Baccour, S.; Albiac, J.; Kahil, T. Cost-Effective Mitigation of Greenhouse Gas Emissions in the Agriculture of Aragon, Spain. Int. J. Environ. Res. Public Health 2021, 18, 1084. [CrossRef] [PubMed]

26. Solazzo, R.; Donati, M.; Tomasi, L.; Arfini, F. How effective is greening policy in reducing GHG emissions from agriculture? Evidence from Italy. Sci. Total Environ. 2016, 573, 1115-1124. [CrossRef]

27. Pleßmann, G.; Blechinger, P. How to meet EU GHG emission reduction targets? A model based decarbonization pathway for Europe's electricity supply system until 2050. Energy Strategy Rev. 2017, 15, 19-32. [CrossRef]

28. European Environment Agency (EEA). Climate Change Adaptation in the Agriculture Sector in Europe; Publications Office of the European Union: Luxembourg, 2019; Available online: https:/ /www.euroseeds.eu/app/uploads/2019/09/Climate-changeadaptation-in-the-agriculture-sector-in-Europe.pdf (accessed on 30 June 2021). 
29. Klimaatakkoord. Proposal for Key Points of the Climate Agreement. 2018. Available online: https://www.klimaatakkoord.nl/ documenten/publicaties / 2018/09/19/proposal-for-key-points-of-the-climate-agreement (accessed on 3 November 2019).

30. Ministère de l'Ecologie, du D.D. Stratégie Nationale Bas-Carbone: Summary for Decision-Makers. 2015. Available online: https:// unfccc.int/files/focus/long-term_strategies/application/pdf/national_low_carbon_strategy_en.pdf (accessed on 30 June 2021).

31. Climate Change Committee (CCC): Carbon Budgets: How We Monitor Emissions Targets. 2019. Available online: http:/ / www.theccc.org.uk/tackling-climate-change/reducing-carbon-emissions/carbon-budgets-and-targets/ (accessed on 30 November 2020).

32. Federal Ministry for the Environment, Nature Conservation, Building and Nuclear Safety (BMUB): Principles and Goals of the German Government's Climate Policy; Federal Ministry for the Environment, Nature Conservation, Building and Nuclear Safety (BMUB) Public Relations Division: Berlin, Germany, 2016.

33. DCCAE. Climate Action Plan 2019: To Tackle Climate Breakdown. Available online: https://assets.gov.ie/10206/d042e174c165 4c6ca14f39242fb07d22.pdf (accessed on 15 July 2021).

34. Bakam, I.; Balana, B.B.; Matthews, R. Cost-effectiveness analysis of policy instruments for greenhouse gas emission mitigation in the agricultural sector. J. Environ. Manag. 2012, 112, 33-44. [CrossRef]

35. Aguilera, E.; Guzmán, G.; Alonso, A. Greenhouse gas emissions from conventional and organic cropping systems in Spain. I. Herbaceous crops. Agron. Sustain. Dev. 2015, 35, 713-724. [CrossRef]

36. Zhang, L.; Zheng, J.; Chen, L.; Shen, M.; Zhang, X.; Zhang, M.; Bian, X.; Zhang, J.; Zhang, W. Integrative effects of soil tillage and straw management on crop yields and greenhouse gas emissions in a rice-wheat cropping system. Eur. J. Agron. 2015, 63, 47-54. [CrossRef]

37. Sáez-Almendros, S.; Obrador, B.; Bach-Faig, A.; Serra-Majem, L. Environmental footprints of Mediterranean versus Western dietary patterns: Beyond the health benefits of the Mediterranean diet. Env. Health 2013, 12, 1-8. [CrossRef] [PubMed]

38. Lassaletta, L.; Billen, G.; Grizzetti, B.; Garnier, J.; Leach, A.M.; Galloway, J.N. Food and feed trade as a driver in the global nitrogen cycle: 50-year trends. Biogeochemistry 2014, 118, 225-241. [CrossRef]

39. European Environment Agency (EEA). Available online: https:/ /ec.europa.eu/eurostat/databrowser/view /ENV_AIR_GGE_ _custom_1118502/default/table?lang=en (accessed on 30 June 2021).

40. Hamed, K.H.; Rao, A.R. A modified Mann-Kendall trend test for autocorrelated data. J. Hydrol. 1998, 204, 182-196. [CrossRef]

41. Mann, H.B. Nonparametric tests against trend. Econom. J. Econom. Soc. 1945, 13, 245-259. [CrossRef]

42. Kendall, M.G. Rank Correlation Methods; Griffin: London, UK, 1975.

43. Yue, S.; Wang, C.Y. Applicability of prewhitening to eliminate the influence of serial correlation on the Mann-Kendall test. Water Resour. Res. 2002, 38, 4-1-4-7. [CrossRef]

44. Sen, P.K. Estimates of the regression coefficient based on Kendall's tau. J. Am. Stat. Assoc. 1968, 63, 1379-1389. [CrossRef]

45. Abdi, H.; Williams, L.J. Principal component analysis. Wiley Interdiscip. Rev. Comput. Stat. 2010, 2, 433-459. [CrossRef]

46. Richardson, M. Principal Component Analysis. Available online: http://people.maths.ox.ac.uk/richardsonm/SignalProcPCA. pdf (accessed on 20 June 2021).

47. Basto, M.; Pereira, J.M. An SPSS R-Menu for Ordinal Factor Analysis. J. Stat. Softw. 2012, 46, 1-29. [CrossRef]

48. MAGRAMA. Anuario de Estadística 2014; MAGRAMA: Madrid, Spain, 2015.

49. MAGRAMA. Encuesta Sobre Superficies y Rendimientos De Cultivos (ESYRCE): Resultados Nacionales y Autonómicos; MAGRAMA: Madrid, Spain, 2015.

50. MAGRAMA. Inventario de Emisiones de Gases de Efecto Invernadero de España. Serie 1990-2014; Informe Resumen, Secretaría de Estado de Medio Ambiente, Dirección General de Calidad y Evaluación Ambiental, MAGRAMA: Madrid, Spain, 2016.

51. Álvaro-Fuentes, J.; Plaza-Bonilla, D.; Arrúe, J.L.; Lampurlanés, J.; Cantero-Martínez, C. Soil organic carbon storage in a no-tillage chronosequence under Mediterranean conditions. Plant Soil. 2014, 376, 31-41. [CrossRef]

52. Albiac, J.; Kahil, T.; Notivol, E.; Calvo, E. Agriculture and climate change: Potential for mitigation in Spain. Sci. Total Environ. 2017, 592, 495-502. [CrossRef] [PubMed]

53. Hijazi, O.; Berg, W.; Moussa, S.; Ammon, C.; von Bobrutzki, K.; Brunsch, R. Comparing methane emissions from different sheep-keeping systems in semiarid regions: A case study of Syria. J. Saudi Soc. Agric. Sci. 2014, 13, 139-147. [CrossRef]

54. Hijazi, O.; Berg, W.; Moussa, S.; Ammon, C.; Von Bobrutzki, K.; Brunsch, R. Awassi sheep keeping in the Arabic steppe in relation to nitrous oxide emission from soil. J. Assoc. Arab. Univ. Basic Appl. Sci. 2014, 16, 46-54. [CrossRef]

55. MAGRAMA. Balance Del Nitrógeno En La Agricultura Española 2012; MAGRAMA: Madrid, Spain, 2014.

56. Romano, D.; Arcarese, C.; Bernetti, A.; Caputo, A.; Cóndor, R.D.; Contaldi, M.; De Lauretis, R.; Di Cristofaro, E.; Federici, S.; Gagna, A.; et al. Italian Greenhouse Gas Inventory 1990-2007. National Inventory Report; ISPRA: Rome, Italy, 2009.

57. Marik, T.; Fischer, H.; Conen, F.; Smith, K. Seasonal variations in stable carbon and hydrogen isotope ratios in methane from rice fields. Glob. Biogeochem. Cycles 2002, 16, 41. [CrossRef]

58. Leip, A.; Bidoglio, G.; Smith, K.A.; Conen, F.; Russo, S. Rice cultivation by direct drilling and delayed flooding reduces methane emissions. InNon-CO2 greenhouse gases: Scientific understanding, control options and policy aspects. In Proceedings of the Third International Symposium, Maastricht, The Netherlands, 21-23 January 2002; pp. 457-458.

59. Schütz, H.; Holzapfel-Pschorn, A.; Conrad, R.; Rennenberg, H.; Seiler, W. A 3-year continuous record on the influence of daytime, season and fertilizer treatment on methane emission rates from an Italian rice padd. J. Geophys. Res. 1989, 94, 16405-16415. [CrossRef] 
60. Schütz, H.; Seiler, W.; Conrad, R. Processes involved in formation and emission of methane in rice paddies. Biogeochemistry 1989, 7, 33-53. [CrossRef]

61. Yan, X.; Yagi, K.; Akiyama, H.; Akimoto, H. Statistical analysis of the major variables controlling methane emission from rice fields. Glob. Chang. Biol. 2005, 11, 1131-1141. [CrossRef]

62. Ortiz, M.; Baldock, D.; Willan, C.; Dalin, C. Towards Net Zero in UK Agriculture Key Information, Perspectives and Practical Guidance; University College London, HSBC UK: London, UK, 2021; p. 55.

63. Nair, P.K.R.; Kumar, B.M.; Nair, V.D. Agroforestry as a strategy for carbon sequestration. J. Plant Nutr. Soil Sci. 2009, 172, 10-23. [CrossRef]

64. National Food Strategy (NFS). 2020. Available online: https://www.nationalfoodstrategy.org/ (accessed on 1 August 2021).

65. Department for Environment Food \& Rural Affairs (Defra). 2021. Available online: https://www.gov.uk/government/statisticaldata-sets / greenhouse-gas-emissions-from-agriculture-indicators (accessed on 1 August 2021).

66. Brown, P.; Cardenas, L.; Choudrie, S.; Jones, L.; Karagianni, E.; MacCarthy, J.; Passant, N.; Richmond, B.; Smith, H.; Thistlethwaite, G.; et al. UK Greenhouse Gas Inventory, 1990 to 2018: Annual Report for Submission under the Framework Convention on Climate Change; Department for Business, Energy \& Industrial Strategy: Oxfordshire, UK, 2020.

67. Ruyssenaars, P.G.; Coenen, P.W.H.G.; Rienstra, J.D.; Zijlema, P.J.; Arets, E.J.M.M.; Baas, K.; Dröge, R.; Geilenkirchen, G.; t Hoen, M.; Honig, E.; et al. Greenhouse gas emissions in the Netherlands 1990-2019; National Inventory Report 2021; National Institute for Public Health and the Environment: Bilthoven, The Netherlands, 2021.

68. Ministry of Environment collaborated with Institute for Studies and Power Engineering. Third Biennial Report of Romania. Romania's Third Biennial Report under the UNFCCC; Ministry of Environment collaborated with Institute for Studies and Power Engineering: Bucharest, Romania, 2017.

69. Poland's National Inventory Report (NIR). Greenhouse Gas Inventory for 1988-2017. Submission under the UN Framework Convention on Climate Change and its Kyoto Protocol; Reporting entity: National Centre for Emission Management (KOBiZE). Institute of Environmental Protection-National Research Institute: Warsaw, Poland, 2019.

70. Piwowar, A. Low-Carbon Agriculture in Poland: Theoretical and Practical Challenges. Pol. J. Environ. Stud. 2018, 28, 2785-2792. [CrossRef]

71. National Inventory Report for France. Inventory of Greenhouse Gas Emissions in France from 1990 to 2019. Under the United Nations Framework Convention on Climate Change and the Kyoto Protocol; Citepa: Paris, France, 2021.

72. Garnier, J.; Le Noë, J.; Marescaux, A.; Sanz-Cobena, A.; Lassaletta, L.; Silvestre, M.; Thieu, V.; Billen, G. Long-term changes in greenhouse gas emissions from French agriculture and livestock (1852-2014): From traditional agriculture to conventional intensive systems. Sci. Total Environ. 2019, 660, 1486-1501. [CrossRef]

73. Fuß, R.; Vos, C.; Rösemann, C.; Greenhouse Gas Emissions from Agriculture. Thünen Institute (TI). Federal Research Institute for Rural Areas, Forestry and Fisheries. 2021. Available online: https:/ /www.thuenen.de/en/topics/climate-and-air/emissioninventories-accounting-for-climate-protection/greenhouse-gas-emissions-from-agriculture/ (accessed on 27 September 2021).

74. Rösemann, C.; Haenel, H.; Vos, C.; Dämmgen, U.; Döring, U.; Wulf, S.; Eurich-Menden, B.; Freibauer, A.; Döhler, H.; Schreiner, C.; et al. Calculations of Gaseous and Particulate Emissions from German Agriculture 1990-2019. Report on Methods and Data (RMD) Submission 2021; Johann Heinrich von Thünen-Institute: Braunschweig, Germany, 2021.

75. German National Inventory Report (NIR). National Inventory Report for the German Greenhouse Gas Inventory from 19902019. Submission under the United Nations Framework Convention on Climate Change and the Kyoto Protocol 2021. Federal Environment Agency. Thünen Institute (TI): Braunschweig, Germany, 2021.

76. Graham, F. Daily briefing: Ground-Breaking Carbon Capture Plant Starts Up. Available online: https://www.nature.com/ articles/d41586-021-02473-y (accessed on 1 August 2021).

77. Peek, M. What Is the Taste of CO2? The Sustainability of Icelandic Food Systems in the Face of Climate Change. Independent Study Project (ISP) Collection. 2016. Available online: https://digitalcollections.sit.edu/isp_collection/2452 (accessed on 1 August 2021).

78. WITS. Available online: https:/ / wits.worldbank.org/CountryProfile/en/Country/ISL/Year/1990/TradeFlow/Import/Partner/ all/Product/16-24_FoodProd\# (accessed on 27 September 2021).

79. Soto, I.; Barnes, A.; Balafoutis, A.; Beck, B.; Sanchez, B.; Vangeyte, J.; Fountas, S.; Wal, T.V.D.; Eory, V.; Gómez-Barbero, M. The Contribution of Precision Agriculture Technologies to Farm. Productivity and the Mitigation of Greenhouse Gas. Emissions in the EU.; EU Science Hub. Publications Office of the European Union: Brussels, Belgium, 2019; ISBN 978-92-79-92834-5. ISSN 1831-9424.

80. Kritikos, M. Precision Agriculture in Europe: Legal and Ethical Reflections for Law-Makers. European Parliament's Science and Technology Options Assessment (STOA); European Parliamentary Research Service (EPRS): Brussels, Belgium, 2017.

81. Euractiv. Europe Entering the Era of 'Precision Agriculture'. 2016. Available online: https://www.euractiv.com/section/sciencepolicymaking/news/europe-entering-the-eraof-precision-agriculture/ (accessed on 27 September 2021).

82. Sadik-Zada, E.R.; Ferrari, M. Environmental Policy Stringency, Technical Progress and Pollution Haven Hypothesis. Sustainability 2020, 12, 3880. [CrossRef] 